\title{
Doprinosi li dnevno vrijeme korištenja medija predviđanju obrazovnih aspiracija učenika na završetku osnovne škole?
}

DOI: $10.5613 /$ rzs.50.2.3

UDK: $316.774-057.87: 373.5$

373.3-057.87:316.774

Izvorni znanstveni rad

Primljeno: 4. 3. 2020.

\section{Gordana KUTEROVAC JAGODIĆ (ID) orcid.org/0000-0001-8186-5046}

Filozofski fakultet Sveučilišta u Zagrebu, Hrvatska

gkuterovac@ffzg.hr

\section{SAŽETAK}

Znatan dio dana adolescenti provode koristeći se suvremenim i tradicionalnim medijima i time su izloženi djelovanju tehnološkoga ekološkog podsustava koji prema razvojnoj teoriji ekoloških sustava može utjecati na različite aspekte njihova razvoja, uključujući i razvoj obrazovnih aspiracija. Cilj ovog istraživanja bio je utvrditi koliko vremena dnevno učenici osmog razreda osnovne škole provode na društvenim mrežama, videoigrama i u gledanju filmova, serija i videouradaka te utvrditi pridonose li te varijable, zajedno s individualnim varijablama roda i školskog uspjeha, obiteljskim varijablama roditeljskog obrazovanja, podrške i očekivanja te obrazovnim i medijskim resursima u kućanstvu, predviđanju učeničkih aspiracija prema gimnazijama ili strukovnim školama. Provjereno je i postoje li razlike u vremenu korištenja medija s obzirom na radni dan ili vikend, rod i obrazovne aspiracije. $U$ istraživanju je sudjelovao 828 učenika osmog razreda zagrebačkih osnovnih škola. Sudionici su imali između 14 i 15 godina, a među njima je bilo $46.4 \%$ djevojčica. Podatci su prikupljeni od učenika upitnicima primijenjenima u školskom okružju. Uz različite medije adolescenti sa strukovnim aspiracijama provode u prosjeku 3 do 6 sati dnevno, a adolescenti s gimnazijskim aspiracijama otprilike 1.5 do 3 sata dnevno. Uz školski uspjeh, spol, socioekonomske i varijable percipirane roditeljske podrške i očekivanja, dnevno vrijeme korištenja medija pokazalo se značajnim ali slabim prediktorom obrazovnih aspiracija učenika na završetku osnovne škole. Više vremena dnevno provedeno u igranju videoigara i gledanju filmova, serija i videa predviđa aspiraciju prema strukovnom obrazovanju učenica i učenika, dok više vremena provedeno na društvenim mrežama predviđa aspiraciju prema strukovnim školama samo kod učenica.

Ključne riječi: suvremeni i tradicionalni mediji, obrazovne aspiracije, roditeljska očekivanja, roditeljska podrška, obrazovni resursi

Zahvaljujemo učenicima, roditeljima i odgojno-obrazovnim radnicima koji su sudjelovali u provedbi istraživanja COBRAS na kojem se temelji ovaj rad. 


\section{UVOD}

Razvoj tehnologije i suvremenih medija promijenio je svakodnevni život djece i adolescenata, osobito stupanj njihove povezanosti s drugima i količinu informacija kojima su izloženi. Mediji su tehnička ili fizička sredstva za prijenos informacija, a masovni se mediji definiraju i kao sustavi koji služe u svrhu javnog informiranja, educiranja i zabave najširih slojeva društva (Jurčić, 2017. U tradicionalne ili masovne medije ubrajaju se tisak, radio i televizija, a osnovno im je obilježje da su institucionalizirani i jednosmjerni izvori informacija pri čemu su njihovi korisnici dominantno pasivni primatelji prezentiranih informacija. $S$ digitalizacijom su se pojavili suvremeni mediji koji za proizvodnju, prezentaciju ili distribuciju sadržaja koriste računalnu tehnologiju, a među njima su najznačajniji internet, videoigre, digitalna televizija i pametni telefoni. Glavna je značajka suvremenih medija višesmjernost komuniciranja izvora i primatelja informacija te aktivnost korisnika. Naime, suvremeni mediji, posredstvom interneta kao sustava umreženih računala, omogućuju korisnicima komuniciranje s izvorima informacija utjecanje na postojeće sadržaje i mijenjanje tih sadržaja, međusobno komuniciranje, ali i kreiranje vlastitih sadržaja (Zgrabljić Rotar, 2017).

Budući da adolescenti velik dio dana provode rabeći medije, oni postaju svojevrsnim socijalizacijskim čimbenikom koji može utjecati na ostvarivanje razvojnih zadaća pa tako i onih koji se tiču odabira obrazovnog puta i zanimanja. Obrazovni i karijerni izbori mladih pod utjecajem su kako raspoloživih mogućnosti i prilika tako i njihovih aspiracija. Aspiracije se definiraju kao sposobnost pojedinca da identificira i postavi ciljeve za budućnost, a koje ga u sadašnjosti nadahnjuju da se trudi kako bi ih postigao (Quaglia i Cobb, 1996). Obrazovne aspiracije mijenjaju se tijekom i nakon djetinjstva, a nastaju i oblikuju se pod utjecajem karakteristika adolescenta i njegove obitelji, vršnjaka, škole i susjedstva. Iskustva sa značajnim drugima, modelima i obrazovnim sustavom, ali i obiteljskog podrijetlo i obiteljski resursi značajni su osobni i socijalni čimbenici formiranja obrazovnih aspiracija (npr. Barr i Dreeben, 1983, Wilson i Wilson, 1992), no aspiracije se oblikuju i pod utjecajem šireg konteksta i povijesnog razdoblja koje uključuje, primjerice, potražnju za osobama određenog stupnja obrazovanja ili zanimanja. Tako se u novije vrijeme zbog popularnosti influencera među mladima, pojavila zabrinutost da oni uzrokuju negativne poglede na važnost obrazovanja i snižavaju obrazovne aspiracije mladih budući da influenceri često postaju slavni i bogati bez puno školovanja (Primary Review, 2007).

Dakle, pojavljuje se potreba da istraživanja razvoja adolescenata uključe i novi okolinski sustav razvoja koji je nazvan tehnološkim ekološkim sustavom (Johnson i Puplampu, 2008) i koji postaje dijelom okolinskih sustava koji utječu na razvoj poje- 
dinca (Bronfenbrenner,1989). Tehnološki podsustav uključuje djetetove interakcije sa živim (npr. vršnjacima) i neživim (npr. vrsta uređaja) elementima informacijskih, komunikacijskih i rekreacijskih tehnologija (IKT) u njegovom okruženju.

\subsection{Mediji kao čimbenik razvoja}

Razvojni zadatci adolescencije su nošenje s tjelesnim sazrijevanjem, uspostavljanje bliskih prijateljstava, integracija u grupu vršnjaka i adekvatna ponašanja u grupi, iniciranje seksualnih odnosa, razvoj ego identiteta, postizanje autonomije, razvoj političke orijentacije i priprema za zanimanje. U tim zadatcima, razvojne svrhe imaju i mediji, kako to ističe Arnett (1995) identificirajući među njima zabavu i traženje novih iskustava i uzbuđenja, identifikaciju važnih aspekata kulture i supkulture mladih, traženje informacija i iskustava koji olakšavaju konstrukciju identiteta te suočavanje i nošenje sa stresorima, poput problema u školi ili teškoća u odnosu s vršnjacima ili romantičnim partnerima. Poput drugih socijalizacijskih čimbenika, mediji mogu djelovati na glavne ciljeve socijalizacije kao što su modeliranje znanja i socijalnih vještina u odnosima s drugima, samoregulacija ponašanja te usvajanje standarda i vrijednosti. Međutim, za razliku od drugih socijalizacijskih čimbenika koji nastoje sačuvati društveni poredak i prenositi vrijednosti kulture, mediji su uvelike tržišno usmjereni te zato često prenose vrijednosti materijalizma i konzumerizma ili nude sadržaje koji nisu najprikladniji za adolescente. Također, mladi nad medijima imaju veću osobnu kontrolu nego nad ostalim socijalizacijskim čimbenicima, a često s njima provode i više vremena nego s odraslima (Arnett, 2015). Osim toga, mladi su također i aktivni akteri u odabiru medija i sadržaja s kojima ulaze $u$ interakciju interpretirajući in i evaluirajući te in u različitoj mjeri prihvaćajući ili odbacujući (Brown, 2006). Nakon što adolescenti vrednuju određeni sadržaj i prihvate ga, on postaje dio njihova identiteta te tako promijenjeni biraju daljnje medijske sadržaje. Konačno, i sami su mediji vrlo heterogeni, od onih čije poruke i sadržaje djeca samo primaju i tumače (poput televizije i radija), do onih (poput interneta i društvenih mreža) gdje mladi mogu i sami slati i kreirati poruke i sadržaje kao i dvosmjerno i višesmjerno komunicirati. Upravo zbog različitosti medija, ali i niza drugih osobnih i okolinskih moderatorskih varijabli, učinci svih medija nisu jednaki. Kako smo u ovom istraživanju ispitivali navike adolescenata u korištenju društvenih mreža, gledanju filmova, TV serija i videouradaka, te igranju videoigara osvrnut ćemo se na istraživanje učinka tih medija. 


\subsubsection{Televizija}

Prva istraživanja utjecaja medija fokusirala su se gotovo isključivo na televiziju, no pojava interneta i mobilnih uređaja te njihova sve veća pristupačnost dovela je do smanjenja količine vremena koje djeca provode gledajući televiziju. Što su djeca starija, to sve manje gledaju televiziju, a i ona koja ju gledaju, sve je manje gledaju u realnom vremenu, a sve više kao televiziju na zahtjev (vidjeti Ofcom, 2019). Najveći broj istraživanja učinka televizije bavio se utjecajem televizijskog nasilja na agresivno ponašanje mladih (Paik i Comstock, 1994), no postoje i dokazi o pozitivnom utjecaju televizije na prosocijalna ponašanja djece i mladih (Mares i Woodard, 2005). Gledanje televizije pokazalo se povezanim s gotovo svim aspektima djetetova razvoja (npr. s prehrambenim navikama i pretilosti), s konzumacijom sredstava ovisnosti (pušenje, alkohol), ranijom seksualnom inicijacijom, rodnim i dobnim stereotipima itd. (Kuterovac Jagodić, Štulhofer i Lebedina Manzoni, 2016). Televizijske serije i filmovi te zabavne emisije vrlo su popularne među učenicima osnovne škole i u Hrvatskoj (llišin, 2003) te djeca i mladi navode kako su im one izvor zabave i opuštanja, način provođenja vremena s obitelji, ali i izvor informacija o mogućim načinima suočavanja s novim i izazovnim životnim situacijama koje prate odrastanje.

\subsubsection{Društvene mreže}

Društvene mreže su interaktivne platforme koje, koristeći internet ili mobilnu tehnologiju, omogućuju korisnicima da konstruiraju svoj javni ili polujavni profil i na njemu odaberu korisnike s kojima će biti povezani te s kojima će komunicirati, stvarati sadržaje, dijeliti in te na njih reagirati (Kietzmann i dr., 2011). Najpoznatije su takve platforme Facebook, Instagram, WhatsApp, Snapchat i brojne druge. Valkenburg i Piotrowski (2017) ističu kako društvene mreže imaju niz funkcionalnosti koje zadovoljavaju razvojne potrebe adolescenata, poput potrebe za formiranjem stabilnog identiteta, za autonomijom u odlučivanju i djelovanju, za bliskošću, prijateljstvom i formiranjem odnosa. Dosadašnja istraživanja pokazuju kako je korištenje društvenih medija "mač s dvije oštrice" jer donosi dobrobiti za adolescente u pogledu mogućnosti izražavanja misli i osjećaja, regulacije raspoloženja, primanja socijalne podrške i smanjenja usamljenosti, ali je povezano i s depresivnošću, sniženim samopoštovanjem, lošom slikom tijela, usamljenošću, pa i nižim zadovoljstvom životom (Keles, McCrae i Grealish, 2020; Webster, Dunne i Hunter, 2020). Mehanizmi kojima se objašnjavaju pozitivni učinci društvenih mreža jesu mogućnost traženja i dobivanja socijalne podrške i pozitivnih povratnih komentara, dok se negativni učinci vežu uz izloženost negativnim komentarima, uzlaznoj socijalnoj 
usporedbi, elektroničkom zlostavljanju i pretjeranom korištenju ili pak pretežito pasivnom korištenju (Orben, 2020). Tako se, primjerice, kod onih koji se društvenim mrežama koriste za usmjereno komuniciranje i povezivanje s prijateljima nalaze pozitivni učinci poput manje usamljenosti, dok se kod onih koji uglavnom pasivno konzumiraju sadržaje pojavljuju negativni učinci poput osjećaja usamljenosti i nedovoljne socijalne povezanosti (Burke, Marlow i Lento, 2010).

Među djecom i mladima osobito je popularna posebna vrsta društvene mreže za gledanje i dijeljenje videa, YouTube. Premda nema podataka za djecu osnovnoškolske dobi, u Hrvatskoj gotovo 98\% srednjoškolaca prati YouTube (Poliklinika za zaštitu djece i mladih Grada Zagreba, 2019). YouTube sve više postaje i platforma za izražavanje kreativnosti i participaciju adolescenata (Jiménez, García i de Ayala, 2016). Premda su među djecom omiljeni videi globalnih glazbenih i filmskih zvijezda i slavnih odraslih YouTubera, sve popularniji postaju adolescenti koji postaju vlogeri, a potom i mikro ili makroinfluenceri (Ofcom, 2019). Djeca ipak u manjoj mjeri kreativno i aktivno sudjeluju u stvaranju videa nego što ih gledaju. Europska istraživanja pokazuju kako djeca nižeg i srednjega socioekonomskog statusa u većem broju imaju otvoren svoj račun na YouTubeu od djece iz obitelji visokog SES-a (Mascheroni i Ólafsson, 2014).

\subsubsection{Videoigre}

Igranje videoigara (engl. gaming) postao je moderan način igre koji upražnjava većina i koji im služe kao izvor zabave, uzbuđenja, izazova, mogućnosti pobjeđivanja i opuštanja (Olson, 2010). Zagovornici videoigara ističu njihove pozitivne učinke na neke aspekte kognicije, na mogućnost zadovoljenja socijalnih potreba putem suradničkih igara i na njihov obrazovni potencijal. Oponenti drže kako digitalne igre ne uključuju kretanje i izravno druženje, kako oduzimaju vrijeme od korisnijih aktivnosti kao što su tradicionalna igra, učenje, čitanje i sport, te kako se o njima može razviti ovisnost. Većina se istraživanja bavila negativnim učincima videoigara poput izazivanja eksternaliziranih problema, posebno agresivnosti (npr. Breuer i dr., 2015; Prot i dr., 2014), dok se manji broj bavio internaliziranim problemima poput depresivnosti (Parkes i dr., 2013). Najmanje je istraživanja koja su ispitivala vezu s problemima pažnje i posljedicama po odnose s vršnjacima (Bioulac, Arfi i Bouvard, 2008). Uz vrstu igara, žanr, samostalno igranje ili igranje s drugima, dnevno vrijeme provedeno u igranju pokazalo se značajnim moderatorom učinka igranja videoigara, s kratkim dnevnim igranjem vezanim uz pozitivne, a dugim uz negativne učinke po psihološku prilagodbu mladih (vidjeti Przybylski, 2014). Utvrđena je i povezanost predugog dnevnog igranja sa slabijom akademskom uključenošću (Przybylski i Mishkin, 2016). Pozitivni učinci igranja videoigara na kognitivne sposobnosti utvr- 
đeni su u područjima prostorne orijentacije, pamćenja, ali i motoričke koordinacije (Bilić, Gjurkić i Kirinić, 2010; Rebetez i Betrancourt, 2007). Jedno istraživanje u Hrvatskoj pokazalo je da većina djece barem ponekad igra edukativne videoigre i vjeruje da igrajući ih može nešto naučiti, primjerice računalne vještine, strateško razmišljanje ili unaprijediti znanje engleskog jezika i kreativnost (Labaš, Marinčić, Mujčinović, 2018). lako je igranje igara privlačnije dječacima nego djevojčicama, rodne se razlike vremenom smanjuju vjerojatno zbog sve većeg broja raspoloživih igara s temama koje zanimaju djevojčice (Valkenburg i Piotrowski, 2017). Djeca koja postanu ovisna o igranju videoigara zanemaruju osnovne potrebe za snom, kretanjem, hranjenjem i druženjem, kao i svoje obveze, osobito one školske. Ovisna o igrama, čini se, češće postaju usamljena djeca, djeca s nižim socijalnim kompetencijama i većom impulzivnošću, a posljedice ovisnosti idu od sniženoga školskog uspjeha, preko anksioznosti i socijalne fobije pa sve do depresivnosti (Gentile i dr., 2012). Neka istraživanja pokazuju kako o igrama ovisna djeca imaju narušene obiteljske odnose (King i Delfabbro, 2017).

\subsection{Mediji kao čimbenik akademske socijalizacije}

Akademska socijalizacija odnosi se na stjecanje normi, vrijednosti i znanja povezanih uz obrazovanje i njegovu važnost i roditelji su najvažniji agensi te vrste. Istraživanja roditeljskog utjecaja na akademsku socijalizaciju bavila su se čimbenicima onoga kakvi su roditelji i obiteljska okolina (roditeljske kognicije o školi, socioekonomski status i sl.) i onime što roditelji čine (roditeljski stil, komunikacija, roditeljska podrška, uključenost u obrazovanje). Roditeljska očekivanja djetetova akademskog uspjeha pokazala su se povezanima s boljim školskim uspjehom djece i kasnijim povoljnim karijernim i financijskim ishodima u odrasloj dobi (Taylor, Clayton i Rowley, 2004). Roditelji se mogu koristiti i edukativnim medijskim sadržajima u svrhu akademske socijalizacije i edukacije svoje djece i poticati na korištenje medija u obrazovne svrhe. Naime, utvrđeni su pozitivni učinci medija u području vizualne inteligencije koji pridonose školskoj spremnosti i uspjehu (Johnson, 2006) te području metakognitivnih procesa planiranja, pretraživanja i evaluiranja koji se razvijaju tijekom pretraživanja interneta (Tarpley, 2001). Jedno longitudinalno istraživanje pokazalo je kako je količina gledanja edukativnih medijskih, prvenstveno televizijskih, sadržaja u predškolskoj dobi pozitivno povezana sa školskim uspjehom u adolescenciji (Anderson i dr., 2001).

Istraživanja koja se tiču povezanosti izloženosti medijima s obrazovnim aspiracijama adolescenata, razmjerno su rijetka i uglavnom usmjerena na adolescente iz deprivilegiranih skupina kao što su djeca etničkih ili rasnih manjina koji se integri- 
raju u novu kulturu (npr. Gordon, 2016). Neka istraživanja polaze od pretpostavke da se kroz medije uči o zanimanjima i tako stvaraju obrazovne i profesionalne aspiracije $\mathrm{i}$ to socijalnim učenjem (imitacijom u medijima istaknutih modela ili kultivacijskim učinkom medija (odabirom zanimanja koja se u medijima prikazuju privlačnima) (npr. Gehrau, Brüggemann i Handrup, 2016)

Školski je uspjeh važan čimbenik akademskih aspiracija, jer učeniku daje povratnu informaciju o tome koliko je dobar u akademskim aktivnostima, a uvelike određuje i mogućnost ostvarivanja aspiracija otvarajući ili zatvarajući put prema višim razinama obrazovanja. Budući da je utvrđena povezanost korištenja medija i školskog uspjeha, moguće je da se veza s obrazovnim aspiracijama ostvaruje tim putem, no još nije jasan smjer te povezanosti. Naime, neka istraživanja pokazuju negativnu (Hancox, Milne i Poulton, 2005), neka pozitivnu povezanost (Li, 2017), a neka čak i njihovu zakrivljenu povezanost, pri čemu umjerena količina korištenja medija pridonosi školskom uspjehu, dok mu velika šteti (Kim i So, 2012). Nedavna velika metaanaliza pokazala je različite povezanosti korištenja medija i školskog uspjeha ovisno o korištenju ukupnog vremena ili vremena provođenja na pojedinim medijima te ovisno o dobi djece i adolescenata (Adelantado-Renau i dr., 2019). Metaanaliza povezanosti vremena korištenja društvenih mreža i školskog uspjeha kod studenata utvrdila je slabu negativnu povezanost, ali nije pronašla učinke dobi niti roda (Huang, 2018). Istraživanja mehanizama povezanosti korištenja medija i školskog (ne)uspjeha podržavaju hipotezu o oduzimanju vremena za učenje i spavanje (Kostyrka-Allchorne, Cooper i Simpson, 2017), ali i hipotezu o poticanju pasivnosti (Sharma i dr., 2017). Tako je, primjerice, utvrđeno kako pretjerano gledanje televizije smanjuje dječju pažnju i misaonu aktivnost (Nathanson, i dr., 2014) te potiče probleme u ponašanju, što šteti učenju i narušava školski uspjeh (Nary, 2004).

Zbog pokazatelja pozitivnih učinaka medija na školski uspjeh i kognitivno funkcioniranje pojavila se bojazan da su djeca koja nemaju pristup internetu zakinuta za razvojne poticaje. Skovan je termin "digitalni jaz" koji nedostatak pristupa internetu i informacijsko-komunikacijskoj tehnologiji povezuje sa smanjenim obrazovnim, financijskim i kulturalnim resursima "informacijski siromašnih" (Livingstone i Helpsper, 2007). "Prvi digitalni jaz" (odnosio se na nejednakosti u pristupu digitalnoj tehnologiji) smanjenjem razlika u pristupačnosti tehnologijama sve se više smanjuje te se u novije vrijeme uočava "drugi digitalni jaz" koji se odnosi na razlike u svrsi korištenja dostupne digitalne tehnologije. Naime, primijećeno je kako se učenici višega SES-a češće koriste informacijsko-komunikacijskom tehnologijom u obrazovne svrhe, dok je oni nižega SES-a češće rabe za igranje i druženje putem socijalnih mreža (Ma, Vachon i Cheng, 2018; van Deursen i van Dijk, 2014). Drži se 
kako je upravo spomenuta razlika u svrsi korištenja tehnologije ono što podržava ili čak pojačava postojeće obrazovne i društvene nejednakosti.

\section{CILJ I PROBLEMI ISTRAŽIVANJA}

Budući da mediji ne djeluju neovisno o roditeljima, koji osiguravaju sredstva, tj. infrastrukturu, za praćenje medija te barem djelomično reguliraju učestalost njihova korištenja kao i sadržaje koje djeca na njima prate, temeljem razvojne teorije ekoloških sustava može se pretpostaviti da ta dva mikrosustava (roditelji i tehnosustav medija) čine mezosustav dom-mediji koji može djelovati na razvoj dječjih obrazovnih aspiracija. Zato je cilj ovog istraživanja bio ispitati je li posjedovanje medijskih resursa kao i dnevno vrijeme korištenja medija, uz osobne čimbenike učenika i socioekonomske i psihološke čimbenike njegove obitelji, povezano s neposrednim obrazovnim aspiracijama učenika osmih razreda osnovne škole. Osim toga, istraživanjem se željelo utvrditi i dnevno vrijeme korištenja suvremenih medija učenika tijekom radnog dana i tijekom vikenda te ispitati postoje li razlike u duljini vremena korištenja medija s obzirom na dane u tjednu, rod i aspiraciju prema različitim vrstama srednje škole. Pretpostavili smo da će bolji školski uspjeh, ženski rod, veći broj obrazovnih resursa, više obrazovanje roditelja, veća podrška majke i oca i njihova veća obrazovna očekivanja biti povezani uz veću vjerojatnost odabira gimnazije nego strukovne škole. Za prediktore raspolaganja medijskim resursima i vremena dnevnog korištenja medija postavili smo dvije alternativne hipoteze: 1) zbog mogućnosti korištenja medija u obrazovne i informativne svrhe veći broj medijskih resursa i dulje dnevno korištenje medija bit će povezano s manjim učinkom prvoga digitalnog jaza, a time i s boljim školskim uspjehom i obrazovnim aspiracijama prema gimnaziji srednjoškolskim programima koji kvalificiraju za upise na fakultet $\mathrm{i}$ 2) zbog mogućnosti korištenja medija u svrhu zabave i druženja veći broj medijskih resursa i dulje dnevno korištenje medija bit će, prema hipotezama o oduzimanju vremena i pasivnosti, biti povezano uz niži školski uspjeh i slabije aspiracije prema studiranju te posljedično biranje strukovnih škola koje omogućuju brži završetak školovanja i ulazak u svijet rada.

\subsection{Sudionici}

Istraživanje je provedeno s učenicima osmih razreda u dobi od 14 do 15 godina u 23 osnovne škole grada Zagreba i dio je trogodišnjega longitudinalnog istraživanja "Obrazovne aspiracije učenika u prijelaznim razdobljima hrvatskoga osnovnoškolskog obrazovanja: priroda, odrednice i promjene" (COBRAS) koje se odvijalo od 2016. do 2019. godine. Spomenute škole predstavljaju stratificirani slučajan uzo- 
rak od $21.9 \%$ svih javnih škola grada Zagreba, pri čemu je stratifikacija provedena na temelju lokacije škole po gradskim četvrtima. U svakoj su školi po slučaju odabrana najmanje dva razredna odjela osmih razreda u kojima su učenici pozvani na sudjelovanje. $U$ ovom su radu prikazani rezultati onih učenika koji su sudjelovali u posljednja dva vala istraživanja i za koje smo imali potpune podatke o korištenju medija i aspiraciji prema vrsti škole, što je činilo uzorak od 871 učenika $(78 \%$ od uzorka u prvom valu) od kojih su 404 (46.4\%) bile djevojčice. Sudjelovanje učenika u istraživanju bilo je dragovoljno, ali uz informirani pismeni pristanak roditelja. Projekt je proveden uz suglasnost Etičkog povjerenstva Instituta za društvena istraživanja u Zagrebu. Odbijanje roditelja po razredu kretalo se od 4 do $8 \%$.Većina učenika iz uzorka živjela je s oba roditelja (84.5\%), 13\% sa samohranim majkama, $1.8 \%$ sa samohranim očevima. Većina učenika imala je jedno ili dvoje braće ili sestara $(48.3 \%$ i $23.3 \%)$, a $14 \%$ njih bili su jedinci. Djeca su pretežno bila iz obitelji u kojima oba roditelja imaju stalno zaposlenje ( $88.6 \%$ očeva i $84.3 \%$ majki). Većina majki $(58.5 \%)$ i očeva $(50.2 \%)$ imalo je završenu višu školu ili fakultet.

\subsection{Postupak}

Podatci korišteni u ovom radu prikupljeni su u posljednje dvije točke longitudinalnog istraživanja obrazovnih aspiracija učenika osnovne škole. Podatci su prikupljani kad su sudionici pohađali osmi razred i to krajem prvoga obrazovnog razdoblja u prosincu i krajem drugoga obrazovnog razdoblja početkom lipnja školske godine 2017./2018. Prikupljanje podataka odvijalo se upitnicima tijekom redovnih nastavnih sati u trajanju od 30 do 40 minuta. $U$ prvoj točki mjerenja prikupljeni su podatci o učestalosti korištenja medija kao i podatci o roditeljskom obrazovanju. Podatci o medijskim i obrazovnim resursima obitelji, djetetovu školskom uspjehu, aspiracijama za srednju školu, roditeljskim očekivanjima i podršci u obrazovnim izborima prikupljeni su drugoj točki mjerenja.

\subsection{Instrumenti}

Obrazovne aspiracije: Aspiracija prema srednjoškolskom obrazovanju ispitana je pitanjem: "Koju vrstu srednjoškolskog obrazovanja želiš upisati?". Učenice i učenici trebali su odabrati između trogodišnjeg ili četverogodišnjega strukovnog obrazovanja, gimnazijskog obrazovanja i kategorije "Ne znam". Zbog malog broja onih koji su izrazili aspiraciju prema trogodišnjoj strukovnoj školi $(7.3 \%)$ učenici s aspiracijama prema dvjema vrstama strukovnog obrazovanja grupirani su, dok su učenici koji su bili neodlučni izuzeti iz daljnjih analiza (4.7\%). Od ukupno preostalih 
828 učenika, aspiraciju prema trogodišnjoj ili četverogodišnjoj strukovnoj školi izrazilo je $50.6 \%$ djece (40.4\% učenica), a prema gimnaziji $49.4 \%$ (59.6\% učenica).

Dnevno vrijeme korištenja medija: Količina korištenja različitih vrsta medija među učenicama i učenicima tipičnim radnim danom i tipičnim danom vikenda ispitano je trima česticama iz Upitnika strukture radnog dana. Učenici su na ljestvici od 7 stupnjeva trebali procijeniti koliko vremena dnevno radnim danom i vikendom najčešće provode na društvenim mrežama (Instagram, Snapchat, Facebook, WhatsApp itd), u igranju videoigara te u gledanju filmova, serija i videouradaka. Učenici su označavali vrijeme korištenja medija u kategorijama: "uopće ne", "1 do 30 min", "30 min do 1 sat", "1 do 2 sata”, " 2 do 3 sata”, "3 do 4 sata" i "više od 4 sata". Za potrebe regresijske analize odgovori na toj kategorijalnoj ljestvici pretvoreni su u kontinuiranu ljestvicu kako je prikazano u Tablicama 2, 3 i 4.

Školski uspjeh: Školski uspjeh ispitan je samoiskazima učenika o zaključnim ocjenama iz svih pojedinih predmeta na kraju osmog razreda osnovne škole, pri čemu je za svrhu analize, kao reprezentativnije mjerilo od općeg uspjeha čija je distribucija izrazito negativno asimetrična, korišten prosjek zaključnih ocjena iz hrvatskog jezika, matematike i prvog stranog jezika. Prosječni uspjeh djece s aspiracijom prema strukovnoj školi bio je "dobar" $(M=3.44, S D=0.75)$ i značajno niži od uspjeha učenika s aspiracijom prema gimnaziji čiji je prosječni uspjeh bio "odličan" $(M=4.65, S D=0.45 ; t=28.12, p<.001)$

Obrazovni status roditelja: Učenici su za svakog roditelja na ljestvici od tri stupnja označili najviši završeni stupanj obrazovanja majke i oca. Na temelju tih odgovora konstruirana je varijabla "obrazovni status roditelja" od pet kategorija: 1 - oba roditelja završena osnovna škola, 2 - jedan roditelj završena osnovna škola drugi srednja škola, 3 - oba roditelja završena srednja škola, 4 - jedan roditelj završena viša škola ili fakultet, a drugi roditelj završena srednja ili osnovna škola i 5 - oba roditelja završena viša škola ili fakultet. U podskupini djece $s$ aspiracijom prema strukovnim školama bilo je najviše roditelja iz kategorije oba roditelja sa srednjom školom (39.4\%), potom iz kategorije jednog roditelja sa srednjom i jednoga s višom školom ili fakultetom (27.2\%) i kategorije oba roditelja s višom školom ili fakultetom $(25.1 \%)$, te najmanje obitelji gdje su oboje roditelja sa završenom samo osnovnom školom (3.3\%) i jedan s osnovnom, a drugi sa srednjom školom (4.8\%). U podskupini djece s aspiracijom prema gimnaziji prevladava kategorija s oba roditelja s višim ili visokim obrazovanjem (58.2\%), potom kombinacija visokoga i srednjoškolskog obrazovanja $(24.4 \%)$ i kategorija oba roditelja sa srednjom školom (17.1\%). $\mathrm{U}$ toj podskupini bio je samo jedan par roditelja s kombinacijom osnovna i srednja škola i niti jedan s oba roditelja s osnovnom školom.

Percepcija roditeljskih očekivanja: Percepcija roditeljskih očekivanja od djece u pogledu obrazovanja ispitana je stupnjem učeničkog slaganja s tvrdnjom "Moji ro- 
ditelji imaju visoka očekivanja od mene u školi” na Likertovoj ljestvici od 1 - uopće se ne slažem, do 5 - u potpunosti se slažem. Učenici koji pretendiraju na gimnazije držali su da njihovi roditelji od njih imaju značajno viša očekivanja $(M=4.14$, $S D=0.85)$ nego što su to procijenili učenici koji su birali strukovnu školu $(M=3.61$, $S D=1.09, t=7.79, p<.001)$.

Majčina i očeva podrška obrazovnim aspiracijama: Roditeljska podrška obrazovnim aspiracijama djece ispitana je dvama zasebnim pitanjima "U kojoj mjeri te majka/otac podržava u tvojim izborima u vezi obrazovanja?" pri čemu su učenici mogli odabrati jedan od pet odgovora ( 1 "nimalo", 2 - "malo", 3 - "osrednje", 4 "dosta" 5 - "izrazito" ). Učenici koji žele upisati strukovnu školu procjenjivali su majčinu $(M=4.29, S D=0.96 ; M=4.65, S D=0.64, t=6.31, p<.001)$ i očevu $(M=4.21$, $S D=1.03 ; M=4.57, S D=0.76, t=5.6, p<.001)$ podršku njihovim obrazovnim izborima slabijom od učenika koji pretendiraju na gimnazije.

Medijski resursi: Medijski resursi u kućanstvima učenica i učenika ispitani su pitanjima o tome imaju li (1) ili nemaju (0) vlastiti mobitel/pametni telefon, računalo koje mogu koristiti, pristup internetu i konzolu za igre (PlayStation, Nintendo, Xbox i sl.). Naknadno je izračunat indeks ukupnih medijskih resursa čiji se mogući raspon kretao od 0 do 4.

Obrazovni resursi: Obrazovni resursi u kućanstvima učenica i učenika ispitani su pitanjima o tome imaju li (1) ili nemaju (0) vlastitu sobu, vlastiti pisaći stol i koliko imaju knjiga u kućanstvu, isključujući časopise i udžbenike. Korištena je ljestvica od 6 kategorija za broj knjiga koja je preuzeta iz PISA istraživanja koje provodi OECD (Gregurović i Kuti, 2010) te se kretala od kategorije 0 do 10 do kategorije više od 500 knjiga. Izračunat je i ukupni indeks obrazovnih resursa čiji je raspon bio od 0 do 4 (stol, soba, broj knjiga ispod medijalne vrijednosti 1 , broj knjiga iznad medijalne vrijednosti 2 boda).

\section{REZULTATI}

\subsection{Posjedovanje medijskih i obrazovnih resursa učenika s obrazovnom aspiracijom za strukovnu školu i gimnaziju}

U Tablici 1 prikazane su frekvencije i postotci učenika koji posjeduju pojedinačne medijske i obrazovne resurse kao i sumarni pokazatelji medijskih i obrazovnih resursa za podskupine djece s različitim obrazovnim aspiracijama. Prema ukupnom broju medijskih resursa podskupine učenika različitih aspiracija značajno se ne razlikuju, no učenici koji aspiriraju prema gimnazijama imaju značajno veći ukupni broj tradicionalnih obrazovnih resursa. Razlika u medijskim resursima proizlazi iz 
pristupa internetu i raspolaganja računalom. Među učenicima koji imaju aspiracije prema gimnaziji značajno veći udio njih ima pristup računalu i internetu nego među učenicima koji pretendiraju na strukovne škole. Međutim, dok je zastupljenost pristupa internetu vrlo visoka i u objema podskupinama prelazi 95\%, najveća je razlika u zastupljenosti pojedinačnih medijskih resursa u posjedovanju računala koje dijete može koristiti i koja je kod djece koja pretendiraju na strukovne škole $8.3 \%$ manja nego kod djece koja žele upisati gimnazije. Gotovo svi učenici u objema podskupinama imaju mobitele ili pametne telefone, a šezdesetak posto ih ima igraće konzole i po tome se dvije skupine međusobno ne razlikuju. Dvije podskupine učenika razlikuju se prema svim pojedinačnim obrazovnim resursima potrebnima za učenje kod kuće koji su svi zastupljeniji kod potencijalnih gimnazijalaca (Tablica 1).

Tablica 1. Medijski i obrazovni resursi obitelji učenika s obrazovnom aspiracijom za strukovnu školu i gimnaziju

\begin{tabular}{|c|c|c|c|c|c|}
\hline & \multicolumn{2}{|c|}{ Strukovna škola } & \multicolumn{2}{|c|}{ Gimnazija } & \multirow[b]{2}{*}{$x^{2}(t)$} \\
\hline & $\begin{array}{c}N \\
(419)\end{array}$ & $\%$ & $\begin{array}{c}N \\
(409)\end{array}$ & $\%$ & \\
\hline \multicolumn{6}{|l|}{ Medijski resursi obitelji } \\
\hline Mobitel djetetov & 414 & 99 & 407 & 99.5 & 1.87 \\
\hline Računalo djetetu na korištenje & 365 & 87.1 & 390 & 95.4 & $17.49^{*+* *}$ \\
\hline Internet & 405 & 96.7 & 406 & 99.3 & $5.76^{\star}$ \\
\hline Igraća konzola & 257 & 61.3 & 236 & 57.7 & 1.14 \\
\hline Ukupno medijski resursi $(M, S D)$ & 3.45 & .691 & 3.52 & .573 & 1.58 \\
\hline \multicolumn{6}{|l|}{ Obrazovni resursi obitelji } \\
\hline Vlastita soba za dijete & 246 & 58.7 & 278 & 68 & $7.03^{* *}$ \\
\hline Radni stol za dijete & 341 & 81.4 & 379 & 92.7 & $23.22^{* * *+}$ \\
\hline \multicolumn{6}{|l|}{ Broj knjiga u kućanstvu } \\
\hline $1.0-10$ & 74 & 17.9 & 13 & 3.2 & \\
\hline 2. $11-25$ & 77 & 18.6 & 40 & 9.9 & \\
\hline 3. $26-100$ & 143 & 34.5 & 122 & 30 & $102.13^{\text {twot }}$ \\
\hline 4. $101-200$ & 72 & 17.4 & 94 & 23.2 & \\
\hline 5. $201-500$ & 33 & 8 & 87 & 21.4 & \\
\hline 6. više od 500 & 15 & 3.6 & 50 & 12.3 & \\
\hline Ukupno obrazovni resursi $(M, S D)$ & 2.7 & 0.88 & 3.2 & 0.78 & $8.65^{\text {tw* }}$ \\
\hline
\end{tabular}

Legenda: Značajnost testiranja razlika $\mathrm{X}^{2}$ testom i t testom: ${ }^{* * *} p<.001 ;{ }^{* *} p<.01 ;{ }^{*} p<.05$ 


\subsection{Dnevno vrijeme korištenja medija ovisno o rodu, danu u tjednu i obrazovnim aspiracijama učenika}

Dnevno vrijeme korištenja pojedinih vrsta medija razmatrali smo s obzirom na rod učenika, na srednju školu koju žele upisati te s obzirom na to je li riječ o uobičajenom radnom danu kad djeca idu u školu ili o uobičajenom danu vikenda. Rezultati su prikazani u Tablicama 2, 3 i 4.

\subsubsection{Društvene mreže}

U Tablici 2 prikazane su samoprocjene duljine dnevnog vremena korištenja društvenih mreža radnim danom i vikendom. Utvrđene su rodne razlike u dnevnom vremenu korištenja društvenih mreža: učenice ih koriste značajno veći broj sati nego učenici i to kako radnim danom $\left(\mathrm{X}_{(1,6)}^{2}=34.6, p<.001\right)$, tako i danima vikenda $\left(X^{2}{ }_{(1,6)}=35.1, p<.001\right)$. Najveći broj učenica radnim danom društvene mreže koristi jedan do dva sata (22\%) i više od 4 sata (21.2\%). Vikendom se dnevno vrijeme korištenja društvenih mreža među učenicama značajno povećava $\left(\mathrm{X}_{(1,36)}^{2}=606.2\right.$, $p<.001)$ tako da ih najveći broj učenica $(25.5 \%)$ koristi vikendom više od 4 sata dnevno. Najveći udio učenika društvene mreže koristi do 30 minuta dnevno $(22.9 \%)$ ili sat do dva sata dnevno (18.1\%). Kod učenika se također u danima vikenda duljina provođenja vremena na društvenim mrežama značajno povećava $\left(X_{(1,36)}^{2}=745.6, p<.001\right)$ te najveći broj učenika provodi na njima jedan do dva sata $(21.6 \%)$, a potom i više od 4 sata $(16.6 \%)$.

Učenici koji aspiriraju prema različitim srednjim školama koriste se društvenim mrežama podjednak broj sati dnevno radnim danima $\left(X_{(1,6)}^{2}=10.9, p=.056\right)$ i vi$\operatorname{kendom}\left(\mathrm{X}_{(1,6)}^{2}=11.1, p<.51\right)$. Vikendom se obje skupine učenika različitih aspiracija koriste društvenim mrežama više vremena nego radnim danima $\left(X_{(1,36)}^{2}=646.4\right.$ $\left.\mathrm{i} \mathrm{X}_{(1,36)}^{2}=751.7, p<.001\right)$. 
Tablica 2. Duljina dnevnog vremena korištenja društvenih mreža radnim danom i vikendom učenika osmog razreda osnovne škole ovisno o rodu i aspiraciji prema različitim vrstama škole

\begin{tabular}{|c|c|c|c|c|c|c|c|c|}
\hline \multirow{4}{*}{$\begin{array}{l}\text { Dnevno } \\
\text { vrijeme }\end{array}$} & \multicolumn{4}{|c|}{ Rod } & \multicolumn{4}{|c|}{ Obrazovna aspiracija } \\
\hline & \multicolumn{2}{|c|}{ Učenice } & \multicolumn{2}{|c|}{ Učenici } & \multicolumn{2}{|c|}{ Strukovna škola } & \multicolumn{2}{|c|}{ Gimnazija } \\
\hline & $\begin{array}{l}\text { Radni } \\
\text { dan }\end{array}$ & & $\begin{array}{c}\text { Radni } \\
\text { dan }\end{array}$ & & $\begin{array}{c}\text { Radni } \\
\text { dan }\end{array}$ & & $\begin{array}{l}\text { Radni } \\
\text { dan }\end{array}$ & \\
\hline & $\%$ & $\%$ & $\%$ & $\%$ & $\%$ & $\%$ & $\%$ & $\%$ \\
\hline Uopće ne & 1.9 & 1.8 & 6.4 & 6.6 & 5.4 & 5.6 & 3.2 & 3.2 \\
\hline $0-30 \mathrm{~min}$ & 13.5 & 10.3 & 22.9 & 14.1 & 19.9 & 12.6 & 17.2 & 12.1 \\
\hline $30 \mathrm{~min}-1 \mathrm{~h}$ & 13.8 & 10.8 & 17.7 & 17.3 & 14.7 & 13.8 & 17.0 & 14.8 \\
\hline $1-2 h$ & 22.0 & 17.9 & 18.1 & 21.6 & 19.4 & 20.0 & 20.4 & 19.7 \\
\hline $2-3 h$ & 18.8 & 19.7 & 13.8 & 14.1 & 12.8 & 12.6 & 19.5 & 20.9 \\
\hline $3-4 h$ & 8.8 & 13.9 & 8.3 & 9.8 & 8.4 & 11.1 & 8.6 & 12.3 \\
\hline više od $4 \mathrm{~h}$ & 21.2 & 25.5 & 12.8 & 16.6 & 19.4 & 24.4 & 14.0 & 17.0 \\
\hline $\mathrm{N}$ & 377 & 380 & 436 & 440 & 407 & 414 & 406 & 406 \\
\hline
\end{tabular}

\subsubsection{Videoigre}

U Tablici 3 prikazane su samoprocjene sati dnevnog vremena igranja videoigara radnim danom i vikendom s obzirom na rod i obrazovne aspiracije. Utvrđene su rodne razlike: učenici dnevno igraju videoigre značajno veći broj sati nego učenice $\mathrm{i}$ to kako radnim danom $\left(\mathrm{X}_{(1,6)}^{2}=356.7, p<.001\right)$, tako $\mathrm{i}$ danima vikenda $\left(X_{(1,6)}^{2}=357.6, p<.001\right)$. Najveći broj učenica uopće ne igra videoigre ni radnim danom (70.1\%) ni vikendom (69.7\%), a od onih koje igraju najveći ih broj to čini od 30 minuta do 1 sata dnevno, kako radnim danom (13.6\%) tako i vikendom $(9.9 \%)$. Iznimno su rijetke učenice koje igraju videoigre više od 4 sata dnevno $(2.1 \%$ radnim danom i $2.7 \%$ vikendom). Usprkos rijetkom igranju videoigara, učenice to ipak češće čine vikendom nego radnim danom $\left(x_{(1,36)}^{2}=679.6, p<.001\right)$. Od učenika koji igraju radnim danom najviše njih igra ih jedan do dva sata $(25.5 \%)$, a vikendom najviše njih igra videoigre više od 4 sata dnevno (21.7\%). Učenici također značajno češće svoje vrijeme provode $u$ igranju videoigara vikendom nego radnim danom $\left(X_{(1,36)}^{2}=594.3, p<.001\right)$. 
Utvrđene su i razlike u duljini dnevnog vremena provedenog u igranju videoigara kod adolescenata različitih obrazovnih aspiracija. Učenici koji aspiriraju prema strukovnim školama igraju videoigre veći broj sati dnevno, kako radnim danima $\left(X_{(1,6)}^{2}=49.4, p<.000\right)$, tako i vikendima $\left(x_{(1,6)}^{2}=38.3, p<.01\right)$ nego učenici koji žele upisati gimnazije. Među onima koji žele upisati strukovnu školu najveći broj njih radnim danom uopće ne igra videoigre (27.9\%), ali zato više od četiri sata dnevno igra čak njih $12.6 \%$. Vikendom se u odnosu na radne dane povećava broj onih koji igraju videoigre, a žele u strukovne škole $\left(\mathrm{X}_{(1,36)}^{2}=706.9, p<.001\right)$, a to povećanje najveće je u kategoriji onih koji igraju dulje od 4 sata dnevno. Među učenicima koji pretendiraju na upis u gimnazije gotovo polovina njih (49.3\%) radnim danom uopće ne igra videoigre, a od onih koji ih igraju najveći broj igra sat do dva dnevno. Vikendom se produžuje dnevno vrijeme igranja za pretendente na gimnazije, posebno u kategoriji više od 4 sata dnevno gdje se udvostručuje broj igrača s $4 \%$ radnim danom na gotovo $8 \%$ vikendima $\left(X_{(1,36)}^{2}=623.9, p<.001\right)$.

Tablica 3. Duljina dnevnog vremena igranja videoigara radnim danom i vikendom kod učenika osmog razreda osnovne škole ovisno o rodu i aspiraciji prema različitim vrstama škole

\begin{tabular}{|c|c|c|c|c|c|c|c|c|}
\hline \multirow[b]{3}{*}{$\begin{array}{l}\text { Dnevno } \\
\text { vrijeme }\end{array}$} & \multicolumn{4}{|c|}{ Rod } & \multicolumn{4}{|c|}{ Obrazovna aspiracija } \\
\hline & \multicolumn{2}{|c|}{ Učenice } & \multicolumn{2}{|c|}{ Učenici } & \multicolumn{2}{|c|}{ Strukovna škola } & \multicolumn{2}{|c|}{ Gimnazija } \\
\hline & $\begin{array}{c}\text { Radni } \\
\text { dan } \\
\%\end{array}$ & $\begin{array}{c}\text { Vikend } \\
\%\end{array}$ & $\begin{array}{c}\text { Radni } \\
\text { dan } \\
\%\end{array}$ & $\begin{array}{c}\text { Vikend } \\
\%\end{array}$ & $\begin{array}{c}\text { Radni } \\
\text { dan } \\
\%\end{array}$ & $\begin{array}{c}\text { Vikend } \\
\%\end{array}$ & $\begin{array}{c}\text { Radni } \\
\text { dan } \\
\%\end{array}$ & $\begin{array}{c}\text { Vikend } \\
\%\end{array}$ \\
\hline Uopće ne & 70.1 & 69.4 & 11.5 & 10.4 & 27.5 & 29.0 & 40.3 & 46.9 \\
\hline $0-30 \mathrm{~min}$ & 13.6 & 9.9 & 10.1 & 6.0 & 12.6 & 8.5 & 10.9 & 7.1 \\
\hline $30 \mathrm{~min}-1 \mathrm{~h}$ & 8.8 & 7.0 & 14.5 & 9.9 & 12.6 & 9.0 & 11.1 & 8.1 \\
\hline $1-2 h$ & 3.2 & 6.2 & 25.5 & 17.1 & 17.3 & 13.7 & 13.1 & 10.3 \\
\hline $2-3 h$ & 1.9 & 2.1 & 14.5 & 18.2 & 10.4 & 10.2 & 6.9 & 11.3 \\
\hline $3-4 h$ & 0.3 & 2.4 & 10.3 & 16.8 & 6.7 & 11.5 & 4.7 & 8.8 \\
\hline više od $4 \mathrm{~h}$ & 2.1 & 2.7 & 13.6 & 21.7 & 12.6 & 18.0 & 4.0 & 7.6 \\
\hline $\mathrm{N}$ & 374 & 373 & 435 & 434 & 405 & 410 & 404 & 397 \\
\hline
\end{tabular}




\subsubsection{Filmovi, serije i videouradci}

U Tablici 4 prikazano je uobičajeno dnevno vrijeme gledanja filmova, serija i videouradaka radnim danom i vikendom kod učenika različitog roda i različitih obrazovnih aspiracija. Za razliku od prethodne dvije vrste medija kod korištenja tih sadržaja nisu utvrđene rodne razlike ni u radnim danima $\left(\mathrm{X}_{(1,6)}^{2}=3.6, p=.729\right)$ ni u danima vikenda $\left(X_{(1,6)}^{2}=7.1, p=.314\right)$. Kao i kod ostalih medija, i ovdje je dulje vrijeme korištenje vikendima nego radnim danima i to kako kod učenica $\left(X_{(1,36)}^{2}=317.6\right.$, $p<.001)$ tako i kod učenika $\left(X_{(1,36)}^{2}=504.1, p<.001\right)$.

No, utvrđene su značajne razlike u dnevnom vremenu korištenja kod adolescenata različitih obrazovnih aspiracija. Učenici koji aspiriraju prema strukovnim školama gledaju filmove, serije i videouratke veći broj sati dnevno nego učenici koji žele upisati gimnazije $\mathrm{i}$ to kako radnim danima $\left(\mathrm{X}_{(1,6)}^{2}=22.9, p<.000\right)$ tako $\mathrm{i}$ vikendima $\left(X_{(1,6)}^{2}=13.6, p=.035\right)$. Premda podjednak i najveći broj onih koji žele u strukovnu školu (25.9\%) i gimnaziju (29\%) gledaju spomenute sadržaje sat do dva dnevno, značajne razlike među tim skupinama u gledanju radnim danom proizlaze iz broja onih koji ih gledaju više od 4 sata. Naime, dvostruko manje pretendenata na gimnazije gleda vikendom filmove, serije i videouratke dulje od 4 sata dnevno od pretendenata na strukovne škole (7.3\% nasuprot $14.1 \%)$. Danima vikenda obje skupine učenika različitih aspiracija gledaju spomenute sadržaje dulje nego što ih gledaju radnim danom $\left(\mathrm{X}_{(1,36)}^{2}=425.6, p<.001 \mathrm{i}_{(1,36)}^{2}=411.4, p<.001\right)$.

Tablica 4. Dnevno vrijeme gledanja filmova, serija i videouradaka radnim danom i vikendom kod učenika osmog razreda osnovne škole, ovisno o rodu i aspiraciji prema različitim vrstama škole

\begin{tabular}{|c|c|c|c|c|c|c|c|c|}
\hline \multirow[b]{3}{*}{$\begin{array}{l}\text { Dnevno } \\
\text { vrijeme }\end{array}$} & \multicolumn{4}{|c|}{ Rod } & \multicolumn{4}{|c|}{ Obrazovna aspiracija } \\
\hline & \multicolumn{2}{|c|}{ Učenice } & \multicolumn{2}{|c|}{ Učenici } & \multicolumn{2}{|c|}{ Strukovna škola } & \multicolumn{2}{|c|}{ Gimnazija } \\
\hline & $\begin{array}{l}\text { Radni } \\
\text { dan }\end{array}$ & Vikend & $\begin{array}{l}\text { Radni } \\
\text { dan }\end{array}$ & Vikend & $\begin{array}{l}\text { Radni } \\
\text { dan }\end{array}$ & Vikend & $\begin{array}{l}\text { Radni } \\
\text { dan }\end{array}$ & Vikend \\
\hline Uopće ne & 5.6 & 2.7 & 5.8 & 5.2 & 3.7 & 4.0 & 7.8 & 4.0 \\
\hline $0-30$ min & 13.2 & 7.3 & 10.9 & 5.7 & 9.9 & 5.5 & 14.1 & 7.3 \\
\hline $\begin{array}{l}30 \mathrm{~min}- \\
1 \mathrm{~h}\end{array}$ & 20.4 & 12.9 & 19.5 & 16.5 & 18.8 & 16.0 & 21.2 & 13.6 \\
\hline $1-2 h$ & 25.3 & 26.3 & 29.3 & 26.7 & 25.9 & 23.1 & 29.0 & 30.1 \\
\hline $2-3 h$ & 16.1 & 19.9 & 17.7 & 18.4 & 19.3 & 17.5 & 14.6 & 20.7 \\
\hline $3-4 h$ & 7.3 & 13.4 & 7.5 & 13.0 & 8.4 & 14.5 & 6.0 & 11.9 \\
\hline 4 hi iviše & 12.1 & 17.5 & 9.5 & 14.4 & 14.1 & 19.3 & 7.3 & 12.4 \\
\hline $\mathrm{N}$ & 372 & 372 & 430 & 423 & 405 & 399 & 397 & 396 \\
\hline
\end{tabular}


Iz podataka za korištenje medija radnim danom i vikendom izračunate su prosječne vrijednosti dnevnog vremena korištenja medija bez obzira na dane u tjednu. Osmoškolci bez obzira na razlike u obrazovnim aspiracijama podjednako koriste društvene mreže i to u prosjeku 2.5 sata dnevno. Međutim, oni koji žele u strukovne škole prosječno dvaput dulje dnevno igraju videoigre (2 sata nasuprot 1 sat) $i$ pola sata dulje gledaju filmove serije i videouratke od onih koji žele u gimnazije (2.5 sata nasuprot 2 sata).

\subsection{Predviđanje učeničkih aspiracija za srednju školu}

Prije pristupanja analizi predviđanja učeničkih aspiracija izračunati su Pearsonovi koeficijenti korelacije između kriterijske varijable aspiracije prema vrsti srednje škole i ostalih prediktorskih varijabli i one su prikazane u Tablici 5. Za utvrđivanje pridonosi li dnevno vrijeme korištenja pojedinih medija povrh sociodemografskih i roditeljskih varijabli, te medijskih i obrazovnih resursa predviđanju obrazovnih aspiracija učenika za srednju školu, upotrijebljena je hijerarhijska binarna logistička regresijska analiza u tri koraka. Zavisna varijabla bila je aspiracija prema upisivanju strukovne škole nasuprot aspiraciji prema upisivanju gimnazije. $U$ prvom bloku uvrštene su varijable djetetova roda i prosječnoga školskog uspjeha iz hrvatskoga, matematike i prvoga stranog jezika na kraju 8. razreda kao i roditeljskoga obrazovnog statusa te količina obrazovnih resursa u obitelji. $U$ drugom su bloku dodane roditeljske varijable vezane uz obrazovanje djeteta: percepcija podrške obrazovnim izborima od strane majke i oca i percepcija roditeljskih očekivanja od djeteta u školi. Konačno u trećem su koraku dodani ukupan broj posjedovanih medijskih resursa i prosječno dnevno vrijeme korištenja triju vrsta medija - društvenih mreža, videoigara te filmova, serija i videouradaka - bez obzira je li riječ o radnom danu ili danu vikenda. Sve su prediktorske varijable tretirane kao kontinuirane.

Dijagnostika modela za prvi blok pokazala je kako su omnibus testovi značajni pri razini rizika manjoj od 1\%, što znači da je prvi model povećao mogućnost predviđanja u odnosu na model sa samom konstantom $\left(X^{2}=512.33, p<.001\right)$. Isto je pokazala i dijagnostika drugog modela u odnosu na prvi $\left(X^{2}=8.60, p=.035\right)$ i trećeg modela u odnosu na drugi $\left(X^{2}=20.40, p<.001\right)$. Hosmer i Lemeshowi testovi za model za sva tri koraka su statistički neznačajni (Tablica 6), što upućuje na to da su modeli dobro prilagođeni podatcima na svim koracima. 


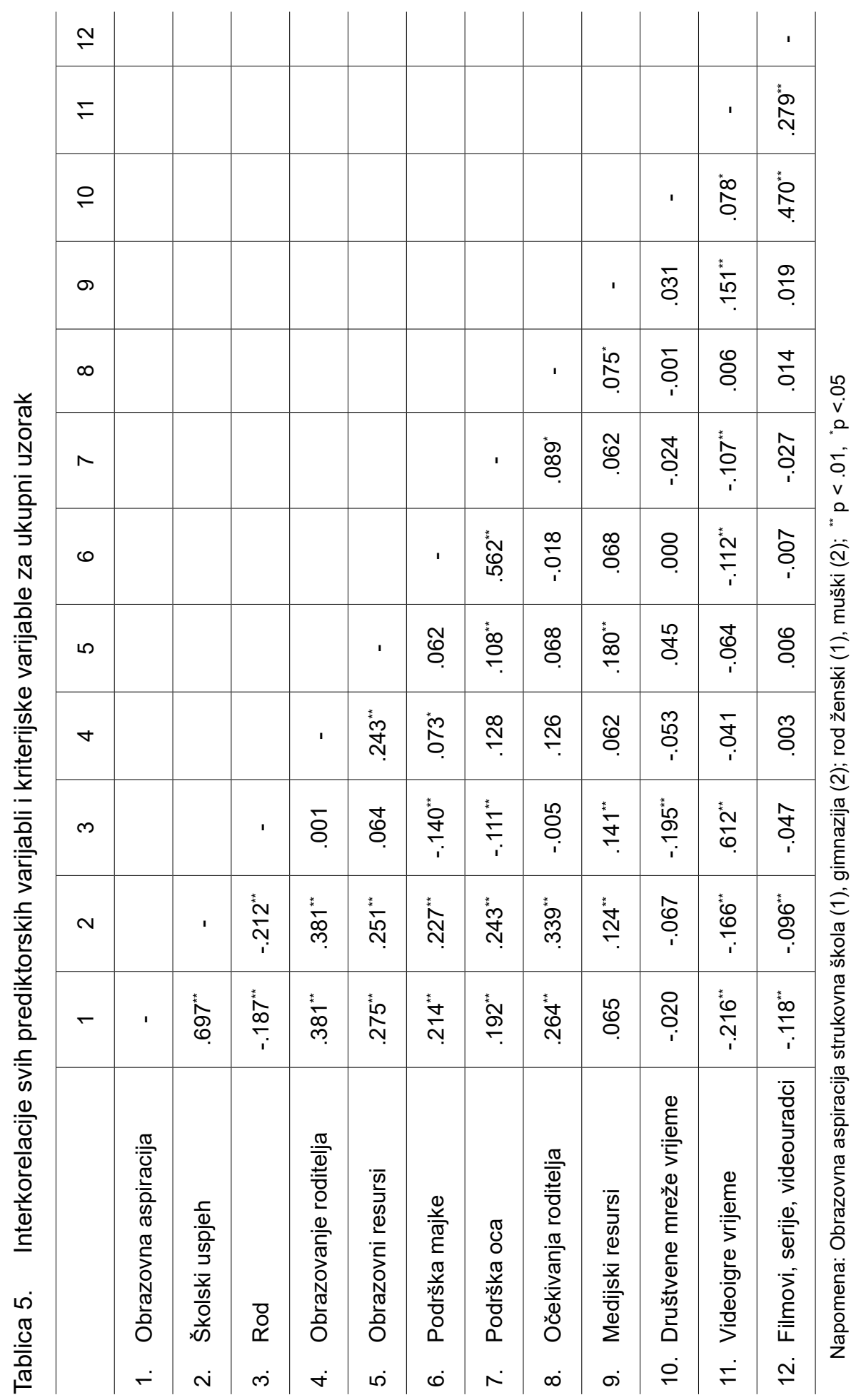




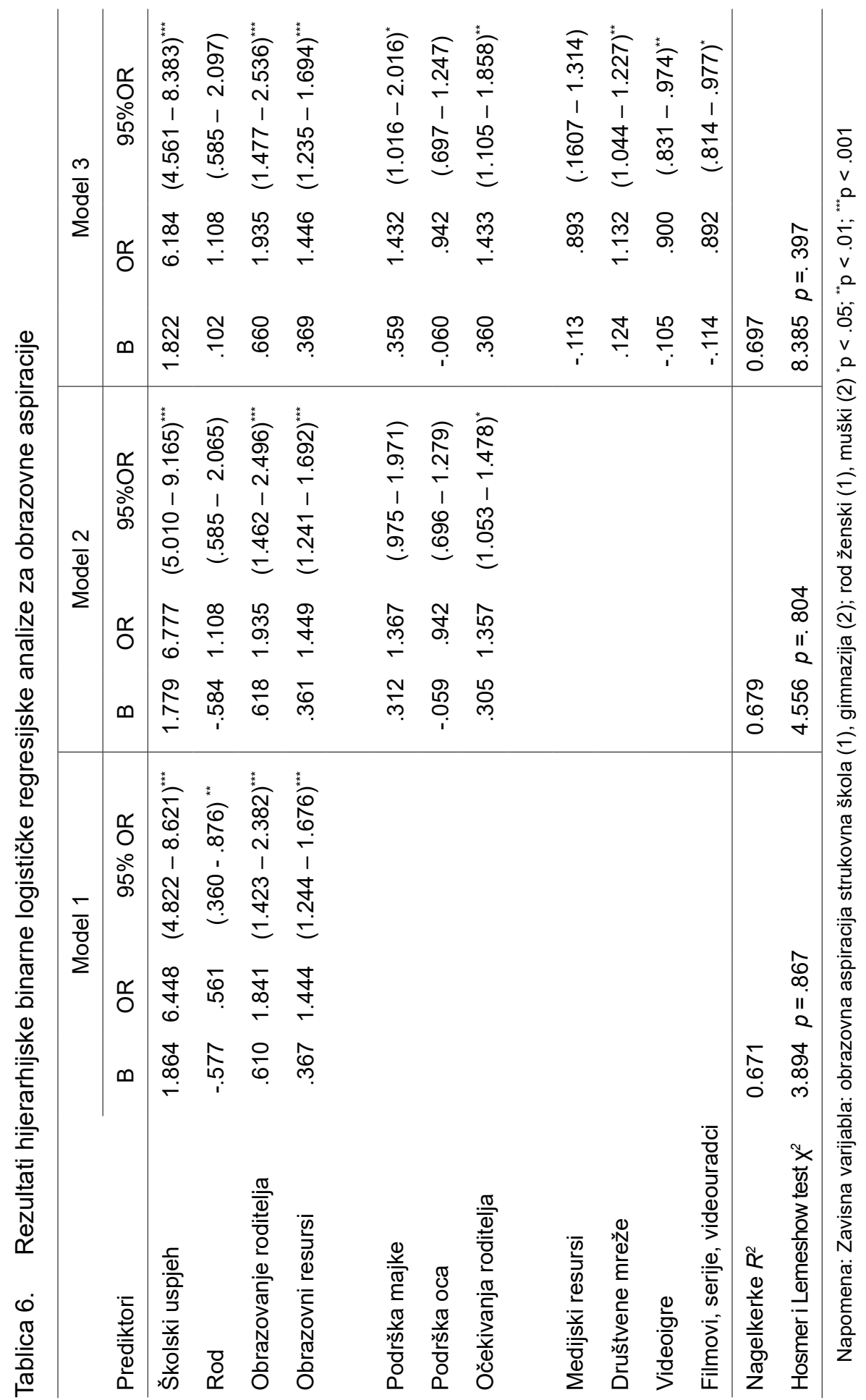


Prvim modelom manje se točno prema aspiracijama klasificiraju učenici koji žele upisati strukovne škole (80.1\%) nego oni koji žele upisati gimnaziju (88.5\%), a ukupna točnost klasifikacije na temelju kontrolnih varijabli iznosi $84.5 \%$. Drugim je modelom moguće uspješno klasificirati $85.6 \%$ učenika, pri čemu je nešto poboljšana predikcija za učenike koji imaju aspiracije prema strukovnoj školi $(82.5 \%)$, dok je predikcija za one koji aspiriraju prema gimnaziji ostala podjednaka (88.2\%). Treći model točno klasificira ukupno $86.6 \%$ učenika i to nešto slabije učenike s aspiracijama prema strukovnim školama (83.1\%), nego one koji aspiriraju prema gimnazijama (89.5\%). Budući da svi pokazatelji upućuju na to da je model za sva tri koraka dobro prilagođen podatcima (Tablica 6), moguće je interpretirati koeficijente binarne logističke regresije $(B)$ i OR ili omjer vjerojatnosti za pojedine prediktore.

U prvom su se koraku analize značajnima pokazali svi prediktori: školski uspjeh učenika na kraju osmog razreda, njihov rod, obiteljski obrazovni resursi i obrazovni status roditelja (Tablica 6). Porastom prosječnoga školskog uspjeha iz ključnih predmeta za jednu ocjenu otprilike 6.4 puta raste vjerojatnost da će učenici imati aspiracije prema gimnaziji. Muški rod smanjuje vjerojatnost da će učenik imati aspiracije prema gimnazijskom obrazovanju. Bolji obrazovni status roditelja za 1.8 puta, a bolji obrazovni materijalni resursi za 1.4 puta povećavaju vjerojatnost da će učenik imati aspiraciju ka upisu u gimnaziju. Od varijabli dodanih u drugom koraku percipirana podrška oca i majke djetetovim obrazovnim težnjama nisu pokazali povezanost s predviđanjem djetetovih aspiracija prema različitim vrstama srednje škole, dok percipirana visoka očekivanja roditelja od djeteta u školi za 1.4 puta povećavaju vjerojatnost da će dijete željeti upisati gimnaziju. Rod učenika izgubio je prediktivnu značajnost. Konačno, u posljednjem su modelu dodane varijable dnevnog vremena korištenja različitih medija koje su se sve pokazale značajnim prediktorima dok samo posjedovanje medijskih resursa nije. Pozitivan B koeficijent ukazuje kako više vremena dnevno provedenog uz društvene mreže 1.1 puta povećava vjerojatnost da će osoba imati aspiracije prema gimnaziji (Tablica 6). No, kako je korelacija vremena provedenog na društvenim mrežama i kriterija nulta (Tablica 5), riječ je zapravo o moderatorskom učinku spola na povezanost tih dviju varijabli. Naime, povezanost vremena provedenog na mrežama i aspiracije prema školi postoji samo kod djevojčica $(r=-.137, p<.001)$, ali ne i kod dječaka $(r=-.007$, $p<.861)$. Dakle, dok se dječaci koji biraju strukovne škole i gimnazije podjednako često koriste društvenim mrežama $(M=2.2, S D=1.6 ; M=2.1, S D=1.5, t=.045, p$ $=.964)$, djevojčice koje biraju strukovne škole značajno više vremena dnevno provode na društvenim mrežama od onih koje biraju gimnazije $(M=3.0, S D=1.6 ; M$ $=2.6, S D=1.5, t=2.65, p=.008$ ). Moderatorski učinak provjeren je regresijskom analizom s kriterijem prosječnoga dnevnog vremena korištenja društvenih mreža u tri koraka u kojoj je u prvom koraku kao prediktor uveden spol $(\beta=-.332, p<.001)$, 
potom vrsta škole $(\beta=-.226, p<.016)$ i na kraju interakcija tih dviju varijabli $(\beta=$ $.232, p<.05)$. Učinci druge dvije vrste medija nisu moderirani spolom i njihovi $B$ koeficijenti pokazuju kako je dulje dnevno vrijeme provedeno u igranju videoigara te dulje dnevno vrijeme provedeno u gledanju filmova, serija i videouradaka povezano s manjom vjerojatnosti da će učenici i učenice težiti upisu u gimnaziju (Tablica 6). Percipirana podrška majke obrazovnim planovima djeteta u posljednjem koraku binarne regresijske analize postaje značajnom pa, kao i percipirana visoka očekivanja roditelja od djeteta u školi, veća podrška i očekivanja za 1.4 puta povećavaju vjerojatnost da će dijete željeti upisati gimnaziju (Tablica 6).

\section{RASPRAVA}

Svrha ovog istraživanja bila je utvrditi pridonosi li promjena u kontekstu razvoja adolescenata koja se odnosi na sve veću prisutnost medija u njihovom svakodnevnom životu razumijevanju učeničkih obrazovnih aspiracija. Zato je cilj ovog istraživanja bio utvrditi dnevno vrijeme korištenja suvremenih medija kod učenika osmih razreda osnovne škole te utvrditi može li poznavanje učeničkih medijskih navika i resursa povrh školskog uspjeha te obiteljskih materijalnih (posjedovanje obrazovnih resursa) i procesnih varijabli (obrazovni status roditelja, percipirana roditeljska očekivanja i podrška) pridonijeti predviđanju njihove srednjoškolske obrazovne aspiracije na kraju osnovne škole. Pretpostavljeno je da će bolji školski uspjeh, ženski rod, veći broj obrazovnih resursa, više obrazovanje roditelja, veća podrška majke i oca i njihova veća obrazovna očekivanja biti povezani uz veću vjerojatnost odabira gimnazije nego strukovne škole dok hipoteze o količini medijskih resursa i njihovoj čestini korištenja nisu bile direktivne.

\subsection{Obrazovni i medijski resursi i obrazovne aspiracije}

Dobiveni rezultati o povezanosti materijalnih obrazovnih resursa obitelji i obrazovanja roditelja s obrazovnim aspiracijama učenika potvrđuju postavljenu hipotezu i ranije dobro potkrijepljene nalaze o povezanosti prihoda i materijalnih resursa za učenje s obrazovnim postignućima (Teachman, 1987). Osmoškolci koji tendiraju strukovnim školama imaju značajno manje obrazovnih resursa (radni stol, zasebna soba i broj knjiga) od osmoškolaca koji žele upisati gimnaziju, a raspolaganje većim brojem obrazovnih resursa predviđa aspiraciju za gimnaziju. Vjerojatno je da je ta veza posredovana povezanošću veće količine obrazovnih resursa s višim školskim uspjehom $(r=.251, p<.01)$. Slična je pozitivna povezanost s uspjehom i aspiracijama utvrđena za obrazovni status roditelja. Osmoškolci koji imaju aspiracije prema gimnaziji u našem istraživanju dolaze iz obitelji s višim obrazovnim sta- 
tusom od onih koji aspiriraju prema strukovnim školama, a i ta se povezanost može objasniti posredovanjem djetetova školskog uspjeha koji je povezan s obrazovnim statusom roditelja $(r=.381, p<.01)$. Naši nalazi potvrđuju one ranije nalaze prema kojima su materijalni resursi općenito nešto slabije povezani s uspjehom nego obrazovanje roditelja (Ganzach, 2000).

Osim ovih nalaza koji potvrđuju mnoge ranije, ispitali smo i to kako su medijski resursi u kućanstvu povezani s učeničkim aspiracijama. Pretpostavili smo kako bi posjedovanje medijskih resursa moglo biti povezano s aspiracijama prema gimnaziji ako se oni koriste većinom za učenje, odnosno s aspiracijom prema strukovnoj školi ako se većinom koriste za zabavu. Samo raspolaganje većim brojem medijskih resursa nije se pokazalo prediktivnim za predviđanje vrste srednjoškolske aspiracije, premda je značajno ali slabo povezano s boljim školskim uspjehom ( $r=$ $.124, p<.01)$. Međutim, bivarijatne korelacije odabira škole s pojedinim medijskim resursima (Tablica 5) pokazuju kako resursi koji služe za igranje (konzola) i komunikaciju (mobitel) nisu značajno povezani s obrazovnim aspiracijama učenika, dok raspolaganje računalom i priključkom na internet jesu $(r=.155, p<.01 ; r=.101, p$ $<$.02). Pritom su osmoškolci koji su i željeli upisati strukovnu školu u manjem broju posjedovali računalo i priključak na internet od onih koji su željeli u gimnaziju.

Osmoškolci s aspiracijama prema strukovnoj školi u većem su broju izvještavali kako češće imaju igraću konzolu nego vlastitu sobu, te kako češće imaju računalo nego svoj radni stol. Dakle, dok praktički sva djeca raspolažu mobitelom ili pametnim telefonom, posjedovanje računala u većoj je mjeri povezano s podskupinama po obrazovnim aspiracijama, a time posredno i po socioekonomskom statusu. Posljednje potvrđuje nalaze istraživanja na američkim adolescentima koje je pokazalo kako posjedovanje pametnog telefona nije povezano s prihodima kućanstva, ali posjedovanje računala jest (Anderson i Jiang, 2018).

\subsection{Dnevno vrijeme korištenja medija i obrazovne aspiracije učenica i učenika}

Rezultati ovog istraživanja pokazuju kako mladi medijske resurse koriste vrlo intenzivno te da dnevno vrijeme provedeno uz medije varira s obzirom na dane $u$ tjednu, rod učenika i njihove obrazovne aspiracije. Kad se zbroji vrijeme sve tri vrste medija, osmoškolci dnevno koriste medije u prosjeku 5.5 sati što odgovara nekim podatcima za djecu u Njemačkoj koja na dan na medijima provode $331 \mathrm{mi}-$ nutu, što je 5.5 sati (Feierabend i Scolari, 2019), ili adolescente u Velikoj Britaniji koji izvještavaju o korištenju medija gotovo 7.5 sati na dan (Statista, 2020). Rezultati su pokazali kako se osmoškolci koriste različitim medijima manje vremena uobičajenim radnim danom kad imaju školu i školske obveze nego danima vikenda 
kad imaju više slobodnog vremena. Rezultati pokazuju ono što je utvrđeno i ranije, a to je kako adolescentice imaju sklonost dužem dnevnom vremenu korištenja društvenih mreža (Pujazon-Zazik i Park, 2010), a mladići duljeg igranja videoigara (Greenberg i dr., 2010; Smahel i dr., 2020). No, gledanju filmova, serija i videouradaka učenici i učenice posvećuju podjednaku količinu vremena prosječnog dana u tjednu. Pretpostavljamo kako je taj izostanak rodnih razlika u gledanju filmova, serija i videouradaka rezultat toga što učenici i učenice mogu birati kakve vrste filmova, serija i videouradaka gledaju te premda provode sličnu količinu vremena u tim aktivnostima, ne znači da gledaju medijske sadržaje s istim temama.

Nisu utvrđene značajne razlike u dnevnom vremenu korištenja društvenih medija kod učenika različitih obrazovnih aspiracija te ono prosječno iznosi nešto manje od 2.5 sata dnevno radnim danom i nešto više od 2.5 sata vikendom. Dobiveni rezultati odgovaraju nekim ranijim nalazima o učestalosti korištenja društvenih mreža u Hrvatskoj koja je samo za Facebook 2014. g iznosila 1 - 2 sata dnevno (Poliklinika za zaštitu djece Grada Zagreba, 2014). Kako djeca koriste više od jedne društvene mreže, nalazi su sličniji američkima koji pokazuju da se više od $30 \%$ adolescenata koristi društvenim mrežama od 30 minuta do 3 sata dnevno (Riehm i dr., 2019). lako razlike u duljini dnevnog korištenju društvenih mreža adolescenata različitih aspiracija nisu nađene na ukupnom uzorku, utvrđene su unutar poduzorka učenica. Dok se učenici koriste društvenim mrežama u podjednakoj mjeri bez obzira na aspiraciju prema vrsti škole, učenice koje pretendiraju na gimnazije manje ih koriste vikendom od onih koje pretendiraju na strukovne škole. Primjerice, u skupini onih koje vikendom koriste društvene mreže više od 4 sata puno je veći broj učenica koje žele u strukovne škole (35\%) nego onih koje žele u gimnazije (19\%).

Utvrdili smo da većina od $70 \%$ učenica uopće ne igra videoigre, to je gotovo isključivo medij dječaka koji igraju dosta vremena kako radnim danom, tako još više vikendom. Naši nalazi odgovaraju podatcima drugog istraživanja djece iz Hrvatske koje je utvrdilo kako $27 \%$ djevojčica i $52 \%$ dječaka igra videoigre svaki dan, a što je vrlo slično prosjeku za 19 europskih zemalja prema kojem videoigre dnevno igra $29 \%$ djevojčica i 59 \% dječaka (Smahel i dr., 2020). Dnevno igranje videoigara puno je zastupljenije kod muških učenika koji pretendiraju na srednje strukovne škole (dnevni prosjek oko 1.5 sat dnevno), nego kod onih koji žele u gimnazije (dnevni prosjek oko $30 \mathrm{~min}$ ).

Naposljetku, gledanje filmova, serija i videouradaka rodno je univerzalna aktivnost, ali su utvrđene značajne razlike u dnevnom vremenu gledanja s obzirom na obrazovne aspiracije adolescenata. Učenici koji žele u strukovne škole provode otprilike 2.5 sata dnevno gledajući te sadržaje, dok potencijalni gimnazijalci provode oko pola sata manje. 
Sveukupno uz sve medije zajedno djeca sa strukovnim aspiracijama provode $u$ prosjeku (bez obzira na to je li riječ o radnom danu ili vikendu) 3 do 6 sati dnevno, a oni s gimnazijskim 1.5 do 3 sata dnevno. Podatci o vremenu na medijima za potencijalne gimnazijalce našeg uzorka slični su onima koji su dobiveni u istraživanju 19 zemalja gdje je europski prosjek bio 167 minuta dnevno (2.78 h), a hrvatski 157 minuta dnevno (2.61h) (Smahel i dr., 2020). Međutim, djeca iz našeg istraživanja koja imaju aspiracije prema strukovnim školama umnogome nadmašuju te hrvatske i europske prosjeke. Razlog tako velikog konzumiranja medija nije u posjedovanju ukupnog broja medijskih uređaja (za zabavu i za učenje), jer adolescenti koji pretendiraju prema strukovnim školama nemaju značajno manje ukupnih medijskih resursa od onih koji pretendiraju prema gimnazijama, no imaju značajno manje računala i priključaka na internet, što bi ukazivalo na prisutnost određenog stupnja "primarnog digitalnog jaza" (Tablica 1).

\subsection{Percipirana roditeljska podrška, roditeljska očekivanja i obrazovne aspiracije učenika}

Istraživanja važnosti obiteljske okoline za obrazovne aspiracije pokazuju pozitivnu povezanost između roditeljskih očekivanja za dijete i njegovih obrazovnih aspiracija (Benner i Mistry, 2007). Postoje različita objašnjenja spomenute povezanosti: jedna tumače da roditeljska očekivanja povećavaju djetetove aspiracije, dok druga drže kako ostvarena školska postignuća utječu na roditeljska očekivanja. Rezultati tog istraživanja pokazuju kako učenici koji imaju aspiracije prema strukovnim školama procjenjuju roditeljska očekivanja od njih u školi nižima nego djeca koja izjavljuju da žele upisati gimnaziju. Ti učenici procjenjuju nižima i podršku koju im daju majka i otac za njihove obrazovne izbore. Učenici koji teže strukovnim školama doživljavaju da in majka i otac "dosta" podržavaju, a djeca koja teže upisu gimnazije doživljavaju da ih majka i otac "izrazito" podržavaju u obrazovnim izborima. Pozitivna je i korelacija školskog uspjeha učenika s roditeljskim očekivanjima $(r=.339, p<.001)$ i majčinom $(r=.227, p<.001)$ i očevom podrškom $(r=.243$, $p<.001$ ) obrazovnim izborima. Konačno, u našem se istraživanju, kako je bilo i pretpostavljeno, potvrdilo da su za predikciju obrazovnih aspiracija prema gimnaziji značajna visoka roditeljska očekivanja od djeteta u školi, dok je hipoteza o važnosti roditeljske podrške potvrđena samo za majke ali ne i očeve. Razlog za neznačajan doprinos očeve podrške, usprkos značajnoj bivarijatnoj korelaciji očeve podrške i odabira vrste škole, vjerojatno leži u visokoj međusobnoj korelaciji percipirane očeve i majčine podrške $(r=.562, p<.001)$. 


\subsection{Uloga medijskih čimbenika u predviđanju obrazovnih aspiracija}

Ovo je istraživanje potvrdilo polaznu pretpostavku o tome da varijable dnevnog vremena korištenja različitih vrsta medija mogu pridonijeti predikciji obrazovnih aspiracija učenika osmog razreda povrh uobičajenih individualnih i roditeljskih varijabli. Premda je doprinos medijskog vremena značajan, on je malen, no ne bi bilo realno niti očekivati velik učinak medija nakon što su glavni snažni prediktori, rod, školski uspjeh i obrazovni status roditelja i obrazovni resursi obitelji točno klasificirali čak $84.5 \%$ učenika. Očekivano, školski se uspjeh pokazao najboljim prediktorom viših obrazovnih aspiracija, a njega slijede viši obrazovni status obitelji, posjedovanje većeg broja obrazovnih resursa te naposljetku ženski rod. Posjedovanje većeg broja medijskih resursa samo po sebi nije doprinosilo predikciji obrazovnih aspiracija, no dnevno vrijeme provedeno uz različite vrste medija jest. Općenito se može reći kako je dulje dnevno vrijeme provedeno uz medije povezano uz obrazovne aspiracije za strukovne škole i uz lošiji školski uspjeh, a školski uspjeh i obrazovne aspiracije su međusobno jako povezani $(r=.697, p<.001)$. To ne iznenađuje jer su i upisi u srednje škole uvjetovani školskim uspjehom u osnovnoj školi, pri čemu je za gimnazije potrebno imati viši školski uspjeh.

U ovom je istraživanju potvrđena druga od dviju alternativnih hipoteza o učinku medija na aspiracije i to u potpunosti za igranje videoigara i gledanje filmova, serija i videouradaka, a samo djelomično za društvene medije. Naime, dulje dnevno korištenje provedeno u igranju videoigara i gledanju filmova, serija i videouradaka predviđaju aspiraciju prema strukovnoj školi kod učenika i kod učenica. Povezanost je vjerojatno barem djelomično posredovana školskim uspjehom. Naime, korištenje tih medija povezano je gotovo isključivo uz zabavu, što znači da vrijeme provedeno na njima može trošiti dnevno vrijeme za učenje. Smanjeno vrijeme u učenju pak dovodi do lošijega školskog uspjeha, a onda i do nižih aspiracija u vezi s budućim obrazovanjem, kako to objašnjava redukcijska hipoteza o uporabi medija i akademskom uspjehu (Nary, 2004). U svom smo uzorku pronašli negativnu korelaciju prosječnoga dnevnog vremena provedenog u igranju videoigara i školskog uspjeha kao i vremena provedenog u gledanju filmova, serija i videouradaka i školskog uspjeha (Tablica 5). Time smo potvrdili nalaze ranijih istraživanja i metaanaliza o negativnoj povezanosti korištenja medija sa školskim uspjehom (npr. Adelantado-Renau i dr., 2019, Kostyrka-Allchorne, Cooper i Simpson, 2017), a potencijalno ukazali i na kaskadno djelovanje slabijega školskog uspjeha na odabir sekundarnog obrazovanja.

Najsnažnijim medijskim prediktorom pokazalo se dnevno vrijeme provedeno na društvenim mrežama, no njegov je doprinos objašnjenju obrazovnih aspiracija moderiran rodom učenika. Učenice koje više vremena dnevno komuniciraju 
društvenim mrežama u većem broju slučajeva imaju aspiracije prema strukovnim školama, dok kod učenika vrijeme korištenja društvenih mreža nije povezano s njihovim obrazovnim izborima. Budući da se učenice u većoj mjeri koriste upravo društvenim mrežama, čini se kako onda one potencijalno mogu imati veći učinak na njihovo raspoloživo vrijeme za učenje, posljedično i za odabir škole. No, moguće je da kod djevojaka odabir strukovne škole može imati veze s većom izloženosti društvenim medijima i putem razvijanja interesa za modu, ljepotu, estradu i sl. Djevojčice s takvim interesima mogu birati strukovne škole koje će im omogućiti karijeru u tim područjima ili in što prije odvesti do završetka školovanja i mogućnosti da se bave nekim od medijski atraktivnih zanimanja.

\section{ZAKLJUČAK}

Ovo je istraživanje ukazalo na važnost medijskoga tehnološkog ekološkog sustava u kojem se odvija svakodnevni život i razvoj učenika, kao i na važnost njihovih medijskih navika u predviđanju obrazovnih aspiracija za srednjoškolsko obrazovanje. Doprinos medija, premda malen u odnosu na druge značajne varijable, pridonosi predviđanju odabira vrste srednjoškolskog programa. Istraživanja su dosad utvrđivala vezu duljine korištenja medija i odabira zanimanja u smislu povezanosti s vrstom preferiranih medijskih sadržaja, a naše je istraživanje pokazalo i povezanost s prvim korakom na putu odabira zanimanja, odnosno s odabirom strukovnog odnosno gimnazijskoga srednjoškolskog obrazovanja. Međutim, odnos varijabli učeničkog vremena korištenja medija i različitih individualnih, socioemocionalnih, obiteljskih varijabli s aspiracijama vrlo je složen i teško ga je razmrsiti, tako da su potrebna daljnja istraživanja. Tako su, primjerice, školski uspjeh, ali i korištenje medija, te obrazovne aspiracije svi povezani s rodom učenika. Obrazovanje roditelja povezano je pak s mogućnošću i osiguravanjem resursa kako tradicionalnih tako i medijskih, s količinom podrške djetetu, ali i očekivanjima od njega pa onda i sa školskim uspjehom koji je pak najbolji prediktor obrazovnih aspiracija.

Premda je naše istraživanje među rijetkim istraživanjima te vrste i provedeno je na velikom uzorku adolescenata na kraju osnovne škole, ono ima i neka ograničenja. Među njima su ona koja se odnose na teškoće kvantificiranja vremena korištenja medija i mogućnost generalizacije rezultata na adolescente niže obrazovanih roditelja i mlade iz drugih dijelova Hrvatske, osobito iz ruralnih područja u kojima su slabiji socioekonomski uvjeti i raspoloživost medijskih i obrazovnih resursa, ali i raspoloživost različitih vrsta škola. Manjkavost ovog istraživanja je u tome što su dnevno vrijeme korištenja medija procjenjivali sami učenici i to na kategorijalnoj skali. Moguće je da učenici nemaju dobar uvid u vrijeme korištenja, ali i da često prakticiraju multitasking, tj. da se istodobno koriste različitim medijima. 
Također, korištenje medija razmatrano je samo kao duljina vremena provedenog na njima, ali ne i u smislu sadržaja koji se pritom konzumiraju (obrazovni, zabavni itd.) ili aktivnosti koje se na njima rade (npr. aktivno ili promatračko korištenje društvenih mreža). Naime, moguće je da različiti medijski sadržaji, poput obrazovnih programa, drukčije djeluju na učenje, ocjene pa onda i na odabir škole, konačno i na kasnije obrazovne aspiracije od primjerice gledanja videa s glazbom ili s porukama influencera. Uzorak osmoškolaca pristran je s obzirom na obrazovni status roditelja te bi u budućim istraživanjima trebalo težiti socioekonomski heterogenijim uzorcima te osobito obratiti pozornost na uključivanje djece iz obitelji niskoobrazovanih roditelja. Nadalje, vremenski kraće korištenje nekih medija u obiteljima niskoga socioekonomskog statusa može biti povezano s fizičkim nedostatkom medijskih uređaja kao što je kućno računalo ili nužnošću njegova dijeljenja s većim brojem ukućana, a ne samo svojevoljnim rjeđim korištenjem. Buduća istraživanja također se ne bi trebala oslanjati isključivo na samoiskaze o korištenju, nego i rabiti objektivnije mjere poput dnevnika, elektroničkog registriranja korištenja medija ili izvještaja roditelja. Zanimljivo bi bilo napraviti i analizu vrste programa koje mladi preferiraju $i$ utvrditi je li to povezano s obrazovnim aspiracijama.

Konačno, ovo istraživanje pokazuje kako različith mediji mogu imati različitu ulogu u obrazovnim aspiracijama dječaka i djevojčica. Dok neki od njih, poput videoigara i gledanja različitih programa i videa potencijalno mogu oduzimati vrijeme od učenja, spavanja ili nekih drugih slobodnih aktivnosti koje bi mogle pridonijeti školskom uspjehu pa i utjecati na obrazovne aspiracije, drugi, poput socijalnih mreža, mogu imati veći učinak na učenice nego na učenike i njihovo stvaranje obrazovnih aspiracija. Rezultati ovog istraživanja sugeriraju kako dnevno korištenje medija kod adolescenata treba postati značajna informacija pri prikupljanju podataka o učenicima u obrazovnom, profesionalno-orijentacijskom i kliničkom kontekstu jer može ukazivati ne samo na izvore teškoća u školskom učenju i psihičkih teškoća, nego imati i posljedice po obrazovni razvojni put učenika i njihove aspiracije za daljnje školovanje. Zaključno, mediji su potencijalno utjecajan novi čimbenik u akademskoj socijalizaciji mladih koji je potrebno dalje istraživati.

\section{Financijska potpora}

Projekt "Obrazovne aspiracije učenika u prijelaznim razdobljima hrvatskog osnovnoškolskog obrazovanja: priroda, odrednice i promjene" (COBRAS) (UIP-2015-096757) financirala je Hrvatska zaklada za znanost kao uspostavni znanstveno-istraživački projekt u razdoblju od veljače 2016. do veljače 2019. godine. 


\section{LITERATURA}

Adelantado-Renau M, Moliner-Urdiales D, Cavero-Redondo I, Beltran-Valls MR, MartínezVizcaíno V i Álvarez-Bueno C (2019). Association Between Screen Media Use and Academic Performance Among Children and Adolescents: A Systematic Review and Meta-Analysis, JAMA Pediatrics, 173 (11): 1058-1067. https://doi.org/10.1001/ jamapediatrics.2019.3176

Anderson DR, Huston AC, Schmitt KL, Linebarger DL, Wright JC i Larson R (2001). Early Childhood Television Viewing and Adolescent Behavior: The Recontact study, Monographs of the Society for Research in Child Development, 66 (1): 1-147. https:// doi.org/10.1111/1540-5834.00121

Arnett JJ (1995). Adolescents' Uses of Media for Self-Socialization, Journal of Youth and Adolescence, 24(5): 519-533. http://dx.doi.org/10.1007/BF01537054

Arnett JJ (2015). Socialization in Emerging Adulthood. From the Family to the Wider World, from Socialization to Self-Socialization. U: Grusec JE i Hastings PD (ur.). Handbook of Socialization: Theory and Research. NY: Guilford Press, 85-108.

Barr R i Dreeben R (1983). How Schools Work. Chicago: University of Chicago Press. https://doi.org/10.1080/00131728409335932

Benner A i Mistry R (2007). Congruence of Mother and Teacher Educational Expectations and Low-Income Youth's Academic Competence, Journal of Educational Psychology, 99 (1):140-153. https://doi.apa.org/doi/10.1037/0022-0663.99.1.140

Bilić V, Gjukić D i Kirinić G (2010). Mogući učinci igranja računalnih igrica i videoigara na djecu i adolescente, Napredak, 151 (2): 195-213.

Bioulac S, Arfi L i Bouvard MP (2008). Attention Deficit/Hyperactivity Disorder and Video Games: A Comparative Study of Hyperactive and Control Children, European Psychiatry, 23 (2): 134-141. https://doi.org/10.1016/j.eurpsy.2007.11.002

Breuer J, Vogelgesang J, Quandt T i Festl R (2015). Violent Video Games and Physical Aggression: Evidence for a Selection Effect among Adolescents, Psychology of Popular Media Culture, 4 (4): 305-328. https://doi.org/10.1037/ppm0000035

Bronfenbrenner $\cup$ (1989). Ecological Systems Theory: Annals of Child Development. Cambridge, MA: Harvard University Press.

Brown JD (2006). Emerging Adults in a Media-Saturated World. U: Arnett JJ i Tanner $\mathrm{JL}$ (ur.). Emerging Adults in America: Coming of Age in the 21st Century. New York: American Psychological Association, 279-299. https://doi.org/10.1037/11381-012

Burke M, Marlow C i Lento T (2010). Social Network Activity and Social Well-Being. $\mathrm{U}$ : Proceedings of the SIGCHI Conference on Human Factors in Computing Systems, 1909-1912. https://doi.org/10.1145/1753326.1753613

Feierabend S i Scolari J (2019). Was Kinder sehen. Eine Analyse der Fernsehnutzung Drei- bis 13-Jähriger 2018), Media Perspektiven, 4: 156-168. https://www.ardwerbung.de/fileadmin/user_upload/media-perspektiven/pdf/2019/0419_Feierabend_ Scolari_2019-05-09.pdf

Ganzach Y (2000). Parent's Education, Cognitive Ability, Educational Expectations and Educational Attainment, British Journal of Educational Psychology, 70 (3): 419 441. https://doi.org/10.1348/000709900158218 
Gehrau V, Brüggemann T i Handrup J (2016). Media and Occupational Aspirations: The Effect of Television on Career Aspirations of Adolescents, Journal of Broadcasting \& Electronic Media, 60 (3): 465-483. https://doi.org/10.1080/08838151.2016.1203319

Gentile DA, Swing EL, Lim CG i Khoo A (2012). Video Game Playing, Attention Problems, and Impulsiveness: Evidence of Bidirectional Causality, Psychology of Popular Media Culture, 1 (1): 62-70. https://psycnet.apa.org/doi/10.1037/a0026969

Gordon MK (2016). Achievement Scripts: Media Influences on Black Students' Academic Performance, Self-Perceptions, and Career Interests, Journal of Black Psychology, 42 (3): 195-220. https://doi.org/10.1177/0095798414566510

Greenberg BS, Sherry J, Lachlan K, Lucas K i Holmstrom A (2010). Orientations to Video Games Among Gender and Age Groups, Simulation \& Gaming, 41 (2): 238-259. https:// doi.org/10.1177/2F1046878108319930

Gregurović M i Kuti S (2010). Učinak socioekonomskog statusa na obrazovno postignuće učenika: primjer PISA istraživanja, Hrvatska 2006, Revija za socijalnu politiku 17 (2): 179-196. https://doi.org/10.3935/rspv17i2.918

Hancox RJ, Milne BJ i Poulton R (2005). Association of Television Viewing During Childhood With Poor Educational Achievement, Archives of Pediatrics \& Adolescent Medicine, 159 (7): 614-618. https://doi.org/10.1001/archpedi.159.7.614

Huang C (2018). Social Network Site Use and Academic Achievement: A Meta-Analysis, Computers and Education, 119: 76-83. https://doi.org/10.1016/j.compedu.2017.12.010

Ilišin V (2003). Mediji u slobodnom vremenu djece i komunikacija o medijskim sadržajima, Medijska istraživanja, 9 (2): 9-34.

Jiménez AG, García BC i de Ayala CLM (2016). Adolescents and Youtube: Creation, Participation and Consumption, Prisma Social, 1: 60-89.

Johnson GM (2006). Internet Use and Cognitive Development: A Theoretical Framework, E-Learning and Digital Media, 3 (4): 565-573. https://doi.org/10.2304/elea.2006.3.4.565

Johnson G i Puplampu K (2008). A Conceptual Framework for Understanding the Effect of The Internet on Child Development: The Ecological Techno-Subsystem, Canadian Journal of Learning and Technology, 34 (1): 19-28. https://doi.org/10.21432/T2CP4T

Jurčić D (2017). Teorijske postavke o medijima - definicije, funkcije i utjecaj, Mostariensia časopis za društvene i humanističke znanosti, 21 (1): 127-136.

Keles B, McCrae N i Grealish A (2020). A Systematic Review: The Influence of Social Media on Depression, Anxiety and Psychological Distress in Adolescents, International Journal of Adolescence and Youth, 25 (1): 79-93. https://doi.org/10.1080/02673843.2019.1590 851

Kietzmann JH, Hermkens K, McCarthy IP i Silvestre BS (2011). Social Media? Get Serious! Understanding the Functional Building Blocks of Social Media, Business Horizons, 54 (3): 241-251. https://doi.org/10.1016/j. bushor.2011.01.005

Kim DH i So WY (2012). The Relationship Between Daily Internet Use Time and School Performance in Korean Adolescents, Open Medicine, 7 (4): 444-449. https://doi. org/10.2478/s11536-012-0019-7

King L i Delfabbro PH (2017). Features of Parent-Child Relationships in Adolescents with Internet Gaming Disorder, International Journal of Mental Health and Addiction 15: 1270-1283. https://doi.org/10.1007/s11469-016-9699-6 
Kostyrka-Allchorne K, Cooper NR i Simpson A (2017). The Relationship Between Television Exposure and Children's Cognition and Behaviour: A Systematic Review, Developmental Review, 44: 19-58. https://doi.org/10.1016/j.dr.2016.12.002

Kuterovac Jagodić G, Štulhofer A i Lebedina Manzoni M (2016). Preporuke za zaštitu djece i sigurno korištenje elektroničkih medija. Zagreb: Agencija za elektroničke medije. https://www.medijskapismenost.hr/preporuke-za-zastitu-djece-i-sigurno-koristenjeelektronickih-medija/

Labaš D, Marinčić I i Mujčinović A (2019). Percepcija djece o utjecaju videoigara: prethodno priopćenje, Communication Management Review, 4: 8-29. https://doi.org/10.22522/ cmr20190137

Li J (2017). Media Use and School Performance, International Journal for Educational Media and Technology, 11 (1): 7-14.

Livingstone S i Helsper E (2007). Gradations in Digital Inclusion: Children, Young People and the Digital Divide, New Media \& Society, 9 (4): 671-696. http://dx.doi. org/10.1177/1461444807080335

Ma JKH, Vachon TE i Cheng S (2019). National Income, Political Freedom, and Investments in R\&D and Education: A Comparative Analysis of the Second Digital Divide Among 15-Year-Old Students, Social Indicators Research, 144 (1): 133-166. https://doi. org/10.1007/s11205-018-2030-0

Mares ML i Woodard E (2005). Positive Effects of Television on Children's Social Interactions: A Meta-Analysis, Media Psychology, 7 (3): 301-322. https://doi.org/10.1207/ S1532785XMEP0703_4

Mascheroni G i Ólafsson K (2014). Net Children Go Mobile: Risks and Opportunities. Second Edition. Milano: Educatt.

Nary S (2004). Exploring Pathways From Television Viewing to Academic Achievement in School Age Children, The Journal of Genetic Psychology, 165 (4): 367-382. https://doi. org/10.3200/GNTP.165.4.367-382

Nathanson Al, Aladé F, Sharp L, Rasmussen EE i Christy K (2014). The Relation Between Television Exposure and Executive Function Among Preschoolers, Developmental Psychology, 50 (5): 1497-1506. https://doi.org/10.1037/a0035714

Ofcom (2019). Children and Parents: Media Use and Attitudes Report 2019. https:// www.ofcom.org.uk/research-and-data/media-literacy-research/childrens/children-andparents-media-use-and-attitudes-report-2019

Olson CK (2010). Children's Motivations for Video Game Play in the Context of Normal Development, Review of General Psychology, 14 (2): 180-187. https://doi. org/10.1037\%2Fa0018984

Orben A (2020). Teenagers, Screens and Social Media: A Narrative Review of Reviews and Key Studies, Social Psychiatry and Psychiatric Epidemiology, 1-8. https://doi. org/10.1007/s00127-019-01825-4

Paik H i Comstock G (1994). The Effects of Television Violence on Antisocial Behavior: A Meta-Analysis, Communication Research, 21 (4): 516-546. https://doi. org/10.1177\%2F009365094021004004

Parkes A, Sweeting H, Wight D i Henderson M (2013). Do Television and Electronic Games Predict Children's Psychosocial Adjustment? Longitudinal Research Using the UK Millennium Cohort Study, Archives of Disease in Childhood, 98 (5): 341-348. https://doi. org/10.1136/archdischild-2011-301508 
Anderson M i Jiang J (2018). Teens, Social Media, and Technology. Pew Research Center, 31. svibnja. https://www.pewresearch.org/internet/2018/05/31/teens-social-mediatechnology-2018/ (5. veljače 2020.)

Poliklinika za zaštitu djece i mladih grada Zagreba (2014). https://www.poliklinika-djeca.hr/ istrazivanja/istrazivanje-o-iskustvima-i-ponasanjima-djece-na-internetu-i-na-drustvenojmrezi-facebook-2/ (3. veljače 2019.)

Poliklinika za zaštitu djece i mladih grada Zagreba (2019). Društvena online iskustva i mentalno zdravlje mladih: rezultati istraživačkog projekta. https://www.poliklinika-djeca. $\mathrm{hr} /$ istrazivanja/rezultati-nacionalnog-istrazivackog-projekta-drustvena-online-iskustva-imentalno-zdravlje-mladih/ (28. siječnja 2020.)

Primary Review (2007). Community Soundings: The Primary Review Regional Witness Sessions. Cambridge: University of Cambridge Faculty of Education. https://cprtrust. org.uk/wp-content/uploads/2013/10/Primary_Review_Community_Soundings_report. pdf. (15. siječnja 2020.)

Prot,S, Anderson C A, Gentile DA, Brown SC i Swing EL (2014). The Positive and Negative Effects of Video Game Play.U: Jordan A B i Romer D (ur.). Media and the Well-Being of Children and Adolescents. New York: Oxford University Press, 109-128.

Przybylski AK (2014). Electronic Gaming and Psychosocial Adjustment, Pediatrics, 134 (3): 716- 722. https://doi.org/10.1542/peds.2013-4021

Przybylski AK i Mishkin AF (2016). How the Quantity and Qualityo of Electronic Gaming Relates to Adolescents' Academic Engagement and Psychosocial Adjustment, Psychology of Popular Media Culture, 5 (2): 145 - 156. https://doi.apa.org/doi/10.1037/ ppm0000070

Pujazon-Zazik Mi Park MJ (2010). To Tweet, or Not to Tweet: Gender Differences and Potential Positive and Negative Health Outcomes of Adolescents' Social Internet Use, American Journal of Men's Health, 4 (1): 77-85. https://doi.org/10.1177/2F1557988309360819

Quaglia RJ i Cobb CD (1996). Toward a Theory of Student Aspirations, Journal of Research in Rural Education, 12 (3): 127-132.

Rebetez C i Betrancourt M (2007). Video Game Research in Cognitive and Educational Sciences, Cognition, Brain, Behaviour, 11 (1): 131-142.

Riehm KE, Feder KA, Tormohlen KN, Crum RM, Young AS, Green KM i Mojtabai R (2019). Associations Between Time Spent Using Social Media and Internalizing and Externalizing Problems Among US Youth, JAMA Psychiatry, 76(12):1266-1273. https:// doi.org/10.1001/jamapsychiatry.2019.2325

Sharma B, Cosme Chavez R, Jeong AS i Nam EW (2017). Television Viewing and its Association With Sedentary Behaviors, Self-Rated Health and Academic Performance Among Secondary School Students in Peru, International Journal of Environmental Research and Public Health, 14 (383): 1-12. https://doi.org/10.3390/ijerph14040383

Smahel D, Machackova H, Mascheroni G, Dedkova L, Staksrud E, Ólafsson K, Livingstone S i Hasebrink U (2020). EU Kids Online 2020: Survey Results from 19 Countries. EU Kids Online. http://www.lse.ac.uk/media-and-communications/research/researchprojects/eu-kids-online (4. veljače 2020.)

Statista (2020). Time spent consuming media per week among children in the United Kingdom (UK) in 2018, by media. https://www.statista.com/statistics/397851/hours-ofmedia-consumption-by-children-by-media-uk/

Tarpley T (2001). Children, the Internet, and Other New Technologies. U: Singer DG i Singer JL (ur.). Handbook of Children and the Media. Thousand Oaks, CA: Sage, 547-556. 
Taylor LC, Clayton JD i Rowley SJ (2004). Academic Socialization: Understanding Parental Influences on Children's School-Related Development in the Early Years, Review of General Psychology, 8 (3): 163-178. https://doi.org/10.1037\%2F1089-2680.8.3.163

Teachman J (1987). Family Background, Educational Resources, and Educational Attainment, American Sociological Review, 52 (4): 548-557. https://doi. org/10.2307/2095300

Valkenburg PM i Piotrowski JT (2017). Plugged in: How Media Attract and Affect Youth. New Haven, London: Yale University Press. https://doi.org/10.12987/ yale/9780300218879.001.0001

van Deursen A i van Dijk J (2014). The Digital Divide Shifts to Diferences in Usage, New Media and Society, 16 (3): 507-526. https://doi.org/10.1177\%2F1461444813487959

Webster D, Dunne L i Hunter R (2020). Association Between Social Networks and Subjective Well-Being in Adolescents: A Systematic Review, Youth \& Society. Elektronička objava teksta prije tiska, 14. svibnja. https://doi.org/10.1177/0044118X20919589

Wilson PM i Wilson J R (1992). Environmental Influences on Educational Aspirations:A Logistic Transform Model, Youth \& Society, 24 (1): 52-70. https://doi. org/10.1177/0044118X92024001003

Zgrabljić Rotar N (2017). Novi mediji digitalnog doba. U: Josić Lj (ur.). Zbornik Informacijska tehnologija i mediji 2016. Zagreb: Sveučilište u Zagrebu, Hrvatski studiji, 57 - 64. 


\title{
Does Daily Media Screen Time Add to the Prediction of Educational Aspirations of Pupils Finishing Elementary School?
}

\author{
Gordana KUTEROVAC JAGODIĆ (D) orcid.org/0000-0001-8186-5046 \\ Faculty of Humanities and Social Sciences, University of Zagreb, Croatia \\ gkuterovac@ffzg.hr
}

\section{ABSTRACT}

Adolescents spend a sizeable amount of daily time using media, consequently exposing themselves to an ecological techno-subsystem which, according to the ecological systems theory, may influence several aspects of their development, including educational aspirations. This research aimed to determine daily screen time 8th-grade pupils spent on social media, video games, and films, TV-series and videos, and to find whether the screen times, in addition to individual variables of gender and school achievement, family variables of parental education, support, expectations and educational and media resources, add to the prediction of preference towards grammars school versus vocational education. Besides, differences in screen times with respect to gender, school preferences, and part of the week (working days or weekends) were examined. The participants were 828 pupils attending the finishing grade of elementary schools in Zagreb, Croatia. The participants' age ranged from 14 to 15, and $46.4 \%$ of them identified themselves as female. The data was collected using selfreported questionnaires administered during school classes. Adolescents who aspire towards vocational schools spend 3 to 6 hours on screen per day, while adolescents with aspirations towards higher secondary education spend 1.5 to 3 hours. In addition to the GPA, gender, socioeconomic variables, and perceived parental support and expectations, daily screen times on different media significantly add to the prediction of adolescents' educational aspirations at the end of primary education. More screen time of playing video games and watching films, TV series, and videos predicts aspiration towards vocational education while more time spent on social media predicts aspiration towards higher secondary education, but only among girls.

Key words: traditional and new media, educational aspirations, parental expectations, parental support, educational resources 
